\title{
SILAC-Based Quantification of TGFBR2-Regulated Protein Expression in Extracellular Vesicles of Microsatellite Unstable Colorectal Cancers
}

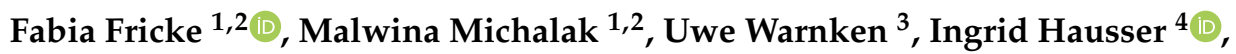 \\ Martina Schnölzer ${ }^{3}$, Jürgen Kopitz ${ }^{1,2}$ and Johannes Gebert ${ }^{1,2, *}$ \\ 1 Department Applied Tumor Biology, Institute of Pathology, Heidelberg University Hospital, \\ Im Neuenheimer Feld 224, 69120 Heidelberg, Germany \\ 2 Clinical Cooperation Unit Applied Tumor Biology, German Cancer Research Center (DKFZ), \\ Im Neuenheimer Feld 224, 69120 Heidelberg, Germany \\ 3 Functional Proteome Analysis, German Cancer Research Center (DKFZ), Im Neuenheimer Feld 581, \\ 69120 Heidelberg, Germany \\ 4 EM-Lab, Institute of Pathology, Im Neuenheimer Feld 224, Heidelberg University Hospital, \\ 69120 Heidelberg, Germany \\ * Correspondence: johannes.gebert@med.uni-heidelberg.de; Tel.: +49-6221-56-4223
}

Received: 17 July 2019; Accepted: 23 August 2019; Published: 26 August 2019

check for updates

\begin{abstract}
Microsatellite unstable (MSI) colorectal cancers (CRCs) are characterized by mutational inactivation of Transforming Growth Factor Beta Receptor Type 2 (TGFBR2). TGFBR2-deficient CRCs present altered target gene and protein expression. Such cellular alterations modulate the content of CRC-derived extracellular vesicles (EVs). EVs function as couriers of proteins, nucleic acids, and lipids in intercellular communication. At a qualitative level, we have previously shown that TGFBR2 deficiency causes overall alterations in the EV protein content. To deepen the basic understanding of altered protein dynamics, this work aimed to determine TGFBR2-dependent EV protein signatures in a quantitative manner. Using a stable isotope labeling with amino acids in cell culture (SILAC) approach for mass spectrometry-based quantification, 48 TGFBR2-regulated proteins were identified in MSI CRC-derived EVs. Overall, TGFBR2 deficiency caused upregulation of several EV proteins related to the extracellular matrix and nucleosome as well as downregulation of proteasome-associated proteins. The present study emphasizes the general overlap of proteins between EVs and their parental CRC cells but also highlights the impact of TGFBR2 deficiency on EV protein composition. From a clinical perspective, TGFBR2-regulated quantitative differences of protein expression in EVs might nominate novel biomarkers for liquid biopsy-based MSI typing in the future.
\end{abstract}

Keywords: extracellular vesicles; exosomes; proteomics; stable isotope labeling with amino acids in cell culture (SILAC); TGFBR2; microsatellite instability; DNA mismatch repair; colorectal cancer

\section{Introduction}

Microsatellite unstable (MSI) colorectal cancers (CRCs) are caused by defects of the DNA mismatch repair system [1]. The MSI phenotype is present in about $15 \%$ of CRCs and is characterized by distinct molecular and clinicopathological features [2,3], which allow precise discrimination from other CRC subtypes. From a clinical perspective, MSI tumors often develop in the proximal colon with inflammatory patterns and invasion into surrounding tissues [2]. Moreover, MSI tumors have a lower propensity to form distant metastases [4,5], and thus often have a better prognosis when compared to microsatellite stable counterparts [6]. In general, MSI tumors show altered chemo-responsiveness emphasizing the importance of alternative therapeutic strategies [7]. Recently, MSI CRCs gained 
increasing attention due to promising clinical responsiveness to immune checkpoint therapies $[8,9]$, which are associated with the molecular mechanisms underlying MSI tumorigenesis. One specific molecular feature of MSI tumors is a high mutational load that results from the accumulation of somatic insertion/deletion mutations in repetitive DNA stretches (i.e., microsatellites) spread over the whole genome. While numerous microsatellite-harboring genes were identified and found to be frequently affected by irrelevant passenger mutations, frameshift mutations in only a limited number of these genes are potential MSI tumor drivers [10-12]. About $90 \%$ of MSI colorectal tumors exhibit inactivating frameshift mutations in a polyadenine (A10) tract in exon 3 of Transforming Growth Factor Beta Receptor Type 2 (TGFBR2) gene [13,14]. TGFBR2 deficiency in colon epithelial cells is considered to drive MSI tumor progression by abrogating downstream Transforming Growth Factor-beta (TGF- $\beta$ ) signaling $[13,15]$. Missense mutations affecting TGFBR2 were also identified in $15 \%$ of microsatellite stable colorectal tumors [16] and in several other tumor types, including breast [17], prostate [18] and renal cell carcinoma [19]. TGFBR2 is a serine/threonine kinase and the primary ligand-binding receptor. After binding of the ligand TGF-B1, TGFBR2 forms a heterodimer complex with TGFBR1, causing conformational changes and signal propagation via canonical (SMAD-dependent) and non-canonical (SMAD-independent) routes. Upon translocation into the nucleus, activated SMAD complexes can interact with various transcription factors to control target gene expression [20,21]. Downstream targets of TGFBR2-mediated signal transduction were identified at the transcriptomic and proteomic level of CRC cells and altered target gene and protein expression has been linked to TGFBR2 deficiency [21-23].

Such altered cellular expression patterns can modulate the molecular cargo of MSI tumor cell-derived extracellular vesicles (EVs). EVs are a heterogeneous population of membrane-enclosed particles that can be classified into different EV subtypes according to their biogenesis and sizes. The two most prominent subclasses are exosomes (30 to $150 \mathrm{~nm}$ ) originating from the endosomal pathway and microvesicles (100 to $1000 \mathrm{~nm}$ ) that are plasma membrane-derived [24,25]. Since exosomes, microvesicles, and other subtypes display overlapping physical and biological properties; current EV isolation methods cannot efficiently isolate individual EV subtypes and a clear consensus allowing discrimination between individual EV subpopulations has not yet been established [24,26]. Apart from difficulties of their classification, shuttling EVs have emerged as an intercellular messaging system used by almost all cells, including CRC cells [27]. The EV-transferred information is encoded by EV cargo molecules, which can elicit a biological response in recipient cells [28]. The EV cargo covers an assortment of membrane and cytosolic components (proteins, nucleic acids, lipids, metabolites) originating from the parental cell [29]. To some extent, the EV cargo reflects the biochemical makeup of parental cells making EVs interesting targets for biomarker discovery and liquid biopsy [30]. In previous work, we have shown that the recurrent MSI tumor driver mutation affecting TGFBR2 can modulate the cargo of MSI tumor cell-derived EVs at a qualitative level [31]. In order to gain a deeper and comprehensive understanding about EV cargo changes caused by TGFBR2 deficiency, the present work aimed to quantify protein differences between EVs derived from TGFBR2-deficient (dT, -dox) and TGFBR2-proficient ( $\mathrm{pT},+$ dox) HCT116 cells genetically modified to confer doxycycline (dox)-inducible TGFBR2 expression in an isogenic background. Stable isotope labeling with amino acids in cell culture (SILAC) combined with high-resolution mass spectrometry identified $48 \mathrm{EV}$ proteins that turned out to be regulated in a TGFBR2-dependent manner.

\section{Results}

\subsection{Isolation and Identification of EVs Secreted by TGFBR2-Deficient and-Proficient MSI Tumor Cells}

In order to quantify the EV protein composition in a TGFBR2-dependent manner, we used our previously established human MSI cell line HCT116-TGFBR2 as a model system [32]. These cells exhibit the MSI phenotype and were genetically modified to confer dox-inducible expression of a single copy TGFBR2 transgene. In the absence of dox, these cells are TGFBR2-deficient (-dox, dT), which mimics the condition of most primary MSI tumors that have lost receptor expression during tumor progression. In contrast, 
in the presence of dox, HCT116-TGFBR2 cells show reconstituted TGFBR2 expression (+dox, pT), which allows the identification of complex molecular changes in an isogenic background. In order to prove the functionality of this MSI model system, we examined the induction of dox-mediated TGFBR2 expression and activation of downstream signaling by Western blot analysis (Supplementary Figure S1). In the absence of dox and in the presence of the ligand TGF- $B 1$ (-dox, +TGF- $B 1$; dT), these cells lacked TGFBR2 and phosphorylated SMAD2 (pSmad2) expression and thus were unable to activate downstream canonical signaling. However, upon exposure to dox and the ligand (+dox, +TGF-B1; pT), these cells showed reconstituted TGFBR2 expression and functional downstream signaling as demonstrated by activation of pSMAD2. After verifying our model system, SILAC conditions were established for HCT116-TGFBR2 cells allowing EV isolation from three biological replicates of heavy-labeled pT-cells and light-labeled dT-cells (Figure 1). The identification of isolated EVs was performed in compliance with the minimal information for studies of extracellular vesicles (MISEV) guidelines [26] using three different approaches.

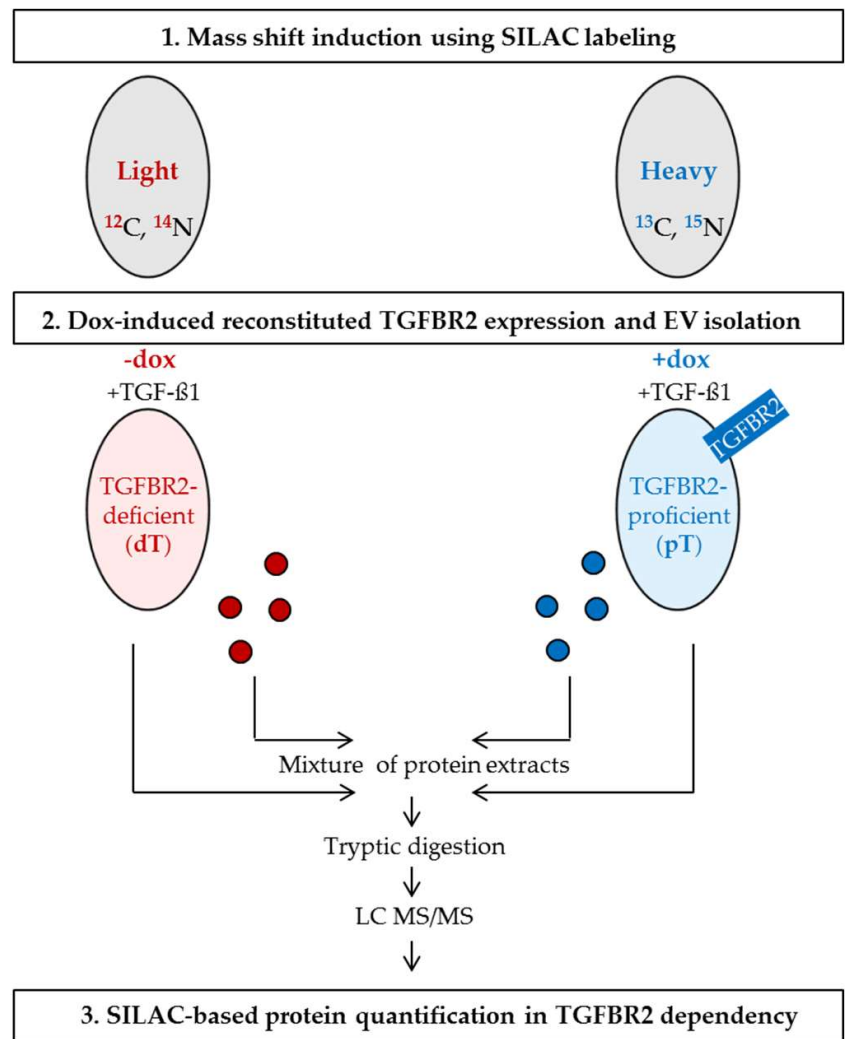

Figure 1. Transforming Growth Factor Beta Receptor Type 2 (TGFBR2)-dependent protein quantification using stable isotope labeling with amino acids in cell culture (SILAC). HCT116-TGFBR2 cells were labeled with light ( $r e d$ ) or heavy (blue) amino acids. The mass shift induction was performed over a period of 14 days. Heavy-labeled cells were treated with dox to induce reconstituted expression of TGFBR2 (heavy state: TGFBR2-proficient, pT). Light-labeled cells were cultivated in the absence of dox and remained TGFBR2-deficient (light state: TGFBR2-deficient, dT). The SILAC experiment was performed in triplicate. Extracellular vesicles (EVs) were isolated and characterized from both conditions. Protein extracts from EVs and their parental cells were mixed separately and prepared for high-resolution mass spectrometry analysis. "Light-to-heavy" (dT/pT) protein ratios were calculated in order to identify proteins regulated in a TGFBR2-dependent manner.

First, transmission electron microscopy was used to visualize the sizes and structures of prepared EVs. As indicated in Figure 2A, EVs were detected as a heterogeneous population of small $(<200 \mathrm{~nm})$ particles showing round and cup-shaped morphologies. 
A
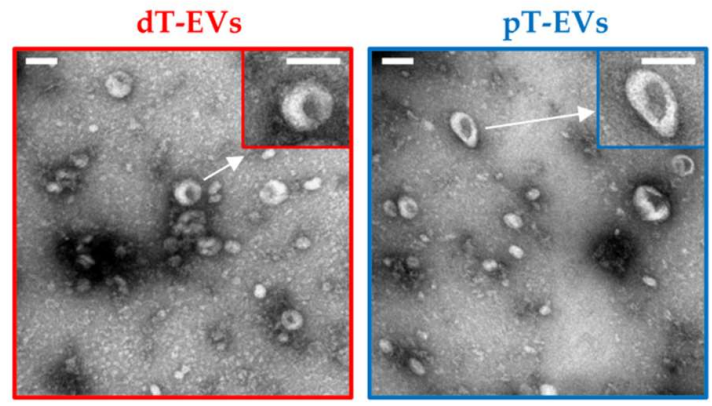

B

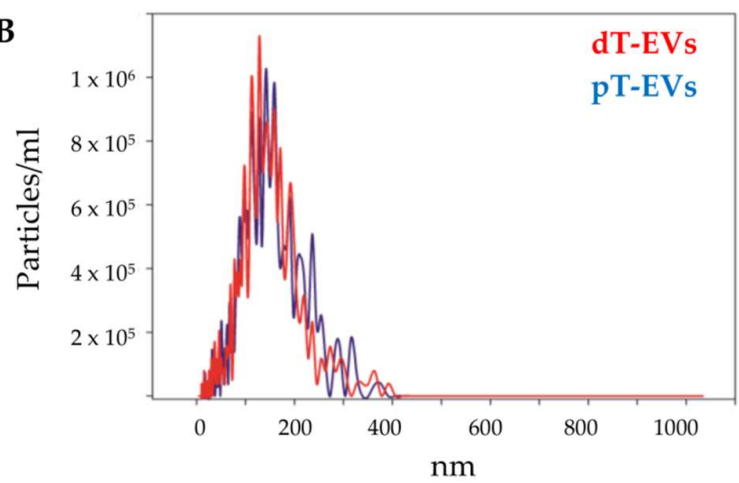

C
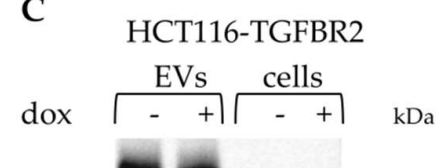

CD63 $30-60$

CD81 26

CD9 - $\quad 24$

TSG101 - - - 46

Alix $\simeq-75$

Calnexin $\quad \longrightarrow \quad 90$

$\beta$-Actin $\quad$ - 42

Figure 2. Identification of EVs. (A) Transmission electron microscopy (TEM) pictures visualized the morphology of isolated EVs. Scale bar: $100 \mathrm{~nm}$. (B) Nanoparticle tracking analysis (NTA) revealed the size distribution and particle concentration of isolated EVs. (C) Western blot analysis confirmed EV-specific and cell-specific protein marker expression. Protein sizes are indicated.

Next, nanoparticle tracking analysis (NTA) confirmed the observed size distributions (Figure 2B). Median sizes of $126.3 \mathrm{~nm}$ (mean $135 \pm 61.1 \mathrm{~nm}$ ) $125.0 \mathrm{~nm}$ (mean $132.6 \pm 63.3 \mathrm{~nm}$ ) were observed for dT-EVs and pT-EVs, respectively. Particle concentrations were calculated resulting in $6.6 \times 10^{10}$ (dT-EVs) and $6.7 \times 10^{10}$ (pT-EVs) particles per $\mathrm{mL}$.

Finally, expression of EV-specific (CD63, CD81, CD9, TSG101, Alix) and cell-specific marker proteins (Calnexin, B-Actin) was analyzed by Western blot analysis (Figure 2C). Membrane-associated tetraspanins CD63, CD81, and CD9 were exclusively detected in EV protein extracts but not in protein lysates of corresponding parental cells. The cytosolic proteins TSG101 and Alix were found to be enriched in protein lysates of EVs compared to their parental cells. Calnexin and cytoskeletal B-Actin were identified in cell lysates but not in EV protein extracts, suggesting efficient EV separation from cells and cellular debris. Altogether, these results demonstrate the successful enrichment of EVs secreted from MSI tumor cells only differing in their TGFBR2 expression status. Herein, no effect of TGFBR2 deficiency on EV sizes, concentrations and protein marker expression was observed. These comprehensively characterized vesicles were used for downstream proteomic analysis.

\subsection{SILAC-Based Quantification of EV Proteins Regulated in a TGFBR2-Dependent Manner}

For accurate SILAC-based quantification of proteins, it is of utmost importance to ensure efficient incorporation of labeled amino acids. Therefore, we first analyzed the mass shift induction in EV protein lysates. Metabolic labeling of parental HCT116-TGFBR2 cells resulted in efficient ( 98\%) incorporation of heavy-labeled amino acids in proteins extracted from EVs (Supplementary Figure S2). Next, peptide mixtures obtained from three biological replicates of dT- and pT-EVs were prepared and analyzed by high-resolution mass spectrometry. In total, $1345 \mathrm{EV}$ proteins were identified (unique peptides $\geq 2$ ) and quantified in at least two out of three biological EV replicates. The quantified EV proteome encompassed 80 proteins of the top $100 \mathrm{EV}$ proteins that have been identified in previous studies [33], thereby confirming the validity of our EV enrichment strategy. In order to 
detect protein candidates differentially expressed between dT- and pT-EVs, "light-to-heavy” (dT/pT) protein ratios were calculated for each replicate and the reproducibility was assessed. Pearson's correlation coefficients $(R)$ revealed a high degree of reproducibility $(R \geq 0.918)$ between all three replicates (Figure 3) allowing quantification of TGFBR2-dependent EV protein profiles. Although the majority (1297/1345) of EV proteins was not altered by the TGFBR2 expression status, a subset of $48 / 1345 \mathrm{EV}$ proteins was found to be significantly $(p<0.05)$ regulated in a TGFBR2-dependent manner (Figure $4 \mathrm{~A}$ ). In particular, $26 / 48 \mathrm{EV}$ proteins turned out to be upregulated and 22/48 EV candidates were found to be downregulated in dT-EVs (Figure 4B). Up- and downregulated EV proteins are listed in Tables 1 and 2, respectively. Protein ratios of downregulated candidates ranged from 0.46- to 0.66-fold. Interestingly, most of them were related to the proteasome (PSMB1, PSMB2, PSMB3, PSMB5, PSMA1, PSMA2, PSMA3, PSMA5, SAFB). In contrast, upregulated candidates encompassed EV proteins whose expression levels were increased 1.50- to 4.73-fold. The majority of these were associated with the organization of extracellular matrix (FN1, FBLN1, COL6A1, COL6A2, THBS1), or the nucleosome (HIST1H4A, HIST1H2BL, HIST2H2BE, H2AFV, H2AFY).
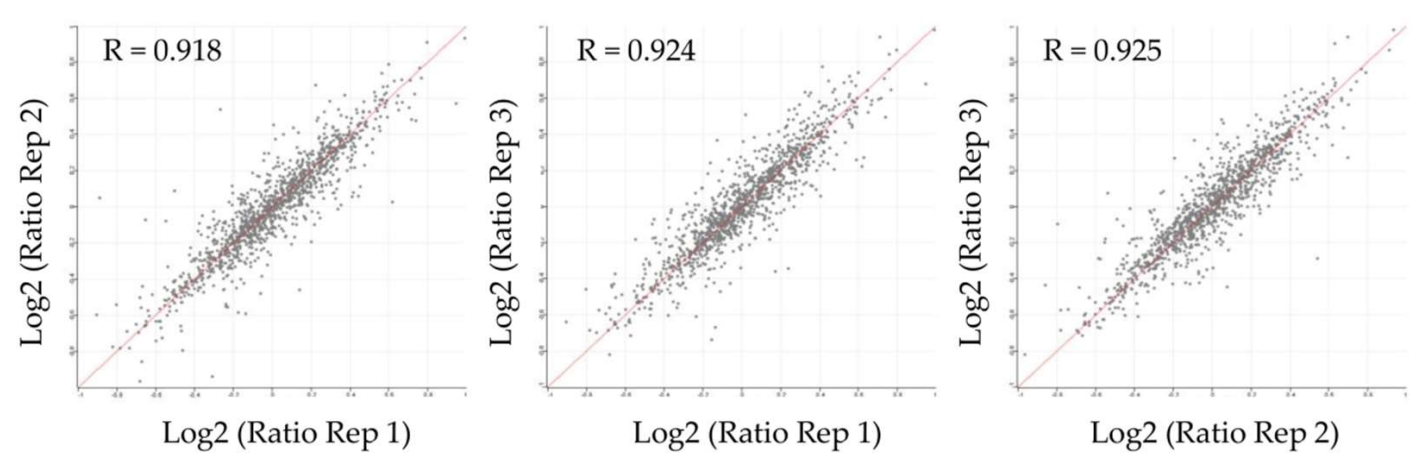

Figure 3. Correlation analysis of protein ratios between biological replicates of EVs. Log2-transformed protein ratios $(\mathrm{dT} / \mathrm{pT})$ of each biological replicate were plotted against each other and Pearson's correlation coefficients $(\mathrm{R})$ were calculated.

A

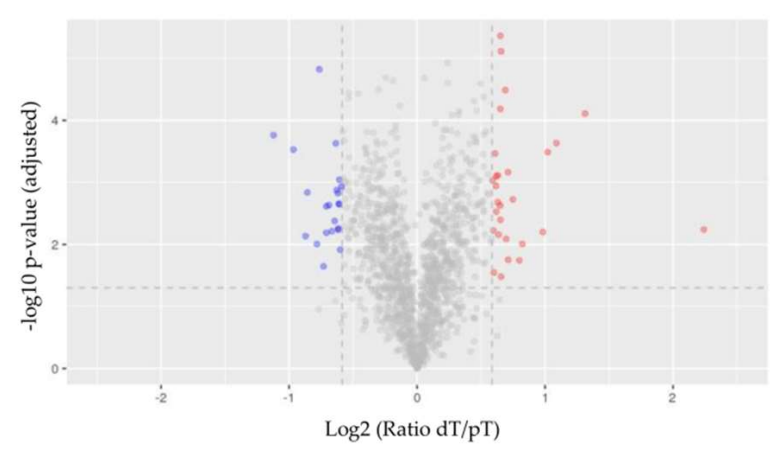

B

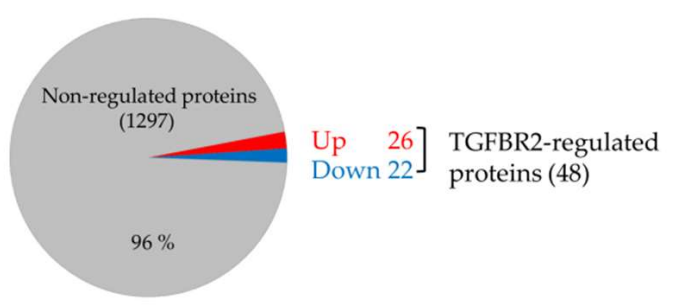

Figure 4. Analysis of TGFBR2-regulated proteins in EVs. (A) Volcano plot shows non-regulated proteins (grey) and significantly up- (red) and downregulated (blue) proteins of EVs derived from TGFBR2-deficient cells. $X$ axis represents $\log _{2}$-transformed fold change values. $Y$ axis shows the $-\log _{10}$ $p$-value adjusted for multiple comparisons; (B) Pie chart specifies non-regulated EV proteins (grey) and EV proteins up- (red) and downregulated (blue) by cellular TGFBR2 deficiency. 
Table 1. 26 Significantly upregulated proteins in dT-EVs.

\begin{tabular}{|c|c|c|c|c|c|c|}
\hline Gene Name & Protein Name & $\begin{array}{l}\text { Protein Ratio } \\
{ }^{1}(\mathrm{dT} / \mathrm{pT})\end{array}$ & $\begin{array}{l}\text { T Test } p \text {-Value } \\
\text { (adj.) }\end{array}$ & $\begin{array}{l}\text { Peptides } \\
\text { (unique) }\end{array}$ & $\begin{array}{l}\text { Coverage } \\
(\%)\end{array}$ & $\begin{array}{c}\text { Identification } \\
\text { Score }\end{array}$ \\
\hline FN1 & Fibronectin & 4.73 & 0.006 & $31(31)$ & 19.7 & 109.14 \\
\hline HIST1H4A & Histone $\mathrm{H} 4$ & 2.48 & $7.79 \times 10^{-5}$ & $8(8)$ & 53.4 & 54.26 \\
\hline HIST1H2BL & Histone H2B type 1-L & 2.13 & $2.33 \times 10^{-4}$ & $6(2)$ & 41.3 & 72.66 \\
\hline HIST2H2BE & Histone H2B type 2-E & 2.03 & $3.25 \times 10^{-4}$ & $6(2)$ & 41.3 & 4.33 \\
\hline $\mathrm{H} 2 \mathrm{AFV}$ & Histone H2A.V & 1.98 & 0.006 & $5(3)$ & 53.9 & 44.88 \\
\hline GLUL & Glutamine synthetase & 1.77 & 0.010 & $6(6)$ & 20.1 & 24.52 \\
\hline C18orf8 & $\begin{array}{l}\text { Uncharacterized } \\
\text { protein C18orf8 }\end{array}$ & 1.74 & 0.018 & $2(2)$ & 4.4 & 2.61 \\
\hline$A N X A 6$ & Annexin A6 & 1.68 & 0.002 & $12(12)$ & 22.3 & 23.43 \\
\hline FBLN1 & Fibulin-1 & 1.64 & 0.018 & $26(13)$ & 51.9 & 323.21 \\
\hline SUB1 & $\begin{array}{l}\text { Activated RNA } \\
\text { polymerase II } \\
\text { transcriptional } \\
\text { coactivator p15 }\end{array}$ & 1.64 & 0.001 & $6(6)$ & 33.9 & 21.71 \\
\hline$R A P 1 B$ & $\begin{array}{l}\text { Ras-related protein } \\
\text { Rap-1b }\end{array}$ & 1.62 & 0.008 & $5(5)$ & 35.9 & 17.40 \\
\hline LTBP4 & $\begin{array}{l}\text { Latent-transforming } \\
\text { growth factor } \\
\text { beta-binding protein } 4\end{array}$ & 1.61 & $3.27 \times 10^{-5}$ & $32(32)$ & 30.8 & 302.21 \\
\hline$M D K$ & $\begin{array}{l}\text { Midkine } \\
\text { Single-stranded }\end{array}$ & 1.58 & $7.74 \times 10^{-6}$ & $5(5)$ & 32.9 & 138.01 \\
\hline SSBP1 & $\begin{array}{l}\text { DNA-binding protein, } \\
\text { mitochondrial }\end{array}$ & 1.57 & 0.004 & $4(4)$ & 29.1 & 8.99 \\
\hline COL6A1 & $\begin{array}{l}\text { Collagen alpha-1(VI) } \\
\text { chain }\end{array}$ & 1.57 & $4.37 \times 10^{-6}$ & $20(20)$ & 26.5 & 323.31 \\
\hline THBS1 & Thrombospondin-1 & 1.57 & $6.54 \times 10^{-5}$ & $50(14)$ & 56.8 & 323.31 \\
\hline CHRD & Chordin & 1.57 & 0.002 & $7(7)$ & 12.5 & 14.76 \\
\hline SEPT6 & Septin-6 & 1.56 & 0.007 & $5(2)$ & 20.0 & 5.35 \\
\hline TNFRSF6B & $\begin{array}{l}\text { Tumor necrosis factor } \\
\text { receptor superfamily } \\
\text { member 6B }\end{array}$ & 1.55 & 0.001 & $3(3)$ & 16.0 & 17.80 \\
\hline LGI3 & $\begin{array}{l}\text { Leucine-rich repeat LGI } \\
\text { family member } 3\end{array}$ & 1.55 & 0.002 & $10(10)$ & 25.0 & 39.49 \\
\hline PURA & $\begin{array}{l}\text { Transcriptional } \\
\text { activator protein } \\
\text { Pur-alpha }\end{array}$ & 1.54 & 0.003 & $3(3)$ & 17.7 & 6.24 \\
\hline COL6A2 & $\begin{array}{l}\text { Collagen alpha-2(VI) } \\
\text { chain }\end{array}$ & 1.54 & 0.001 & $12(12)$ & 18.4 & 58.43 \\
\hline GDF15 & $\begin{array}{l}\text { Growth/differentiation } \\
\text { factor } 15\end{array}$ & 1.53 & 0.001 & $20(20)$ & 65.3 & 127.44 \\
\hline HMGN2 & $\begin{array}{l}\text { Non-histone } \\
\text { chromosomal protein } \\
\text { HMG-17 }\end{array}$ & 1.53 & $3.42 \times 10^{-4}$ & $3(3)$ & 16.7 & 6.75 \\
\hline$H 2 A F Y$ & $\begin{array}{l}\text { Core histone } \\
\text { macro-H2A.1 }\end{array}$ & 1.51 & 0.006 & $8(8)$ & 34.4 & 26.84 \\
\hline MATN2 & Matrilin-2 & 1.50 & 0.001 & $23(23)$ & 31.2 & 190.93 \\
\hline
\end{tabular}

${ }^{1}$ Mean ratios calculated from three biological replicates.

Given the fact that 48/1345 EV proteins turned out to be regulated in a TGFBR2-dependent manner, we sought to determine whether this regulation might reflect changes in the proteome of parental cells or might be found exclusively at the vesicular level. Therefore, peptide mixtures of corresponding parental dT- and pT-cells were prepared and analyzed. In cellular protein extracts, a total of 2140 proteins was identified and quantified in at least two out of three biological replicates. Among these, 1035 proteins were previously found to be also present in EVs (Figure 5). This finding implies that $48 \%(1035 / 2140)$ of cellular proteins appeared to be sorted into EVs, which highlights the general overlap of proteins between MSI CRC cells and their secreted EVs. In this shared subset, we cannot determine any quantitative differences in protein expression between MSI cells and their EVs, because of differences in their proteome complexity and the lack of an appropriate normalization 
strategy. Apart from this shared subset, EV-specific (310/1345) as well as cell-specific protein subsets $(1105 / 2140)$ were identified.

Table 2. 22 Significantly downregulated proteins in dT-EVs.

\begin{tabular}{|c|c|c|c|c|c|c|}
\hline Gene Name & Protein Name & $\begin{array}{c}\text { Protein Ratio } \\
{ }^{1}(\mathrm{dT} / \mathrm{pT})\end{array}$ & $\begin{array}{c}\text { T Test } p \text {-Value } \\
\text { (adj.) }\end{array}$ & $\begin{array}{l}\text { Peptides } \\
\text { (unique) }\end{array}$ & $\begin{array}{c}\text { Coverage } \\
(\%)\end{array}$ & $\begin{array}{c}\text { Identification } \\
\text { Score }\end{array}$ \\
\hline PLAU & $\begin{array}{l}\text { Urokinase-type plasminogen } \\
\text { activator }\end{array}$ & 0.46 & $1.73 \times 10^{-4}$ & $16(16)$ & 50.6 & 323.31 \\
\hline CTGF & Connective tissue growth factor & 0.51 & $2.95 \times 10^{-4}$ & $15(15)$ & 55.3 & 66.74 \\
\hline PSMB1 & Proteasome subunit beta type- 1 & 0.55 & 0.007 & $5(5)$ & 29 & 12.98 \\
\hline PSMB5 & Proteasome subunit beta type- 5 & 0.55 & 0.001 & $5(5)$ & 25.5 & 20.07 \\
\hline PSMA2 & Proteasome subunit alpha type- 2 & 0.58 & 0.010 & $4(4)$ & 21.4 & 20.44 \\
\hline MCM7 & $\begin{array}{l}\text { DNA replication licensing factor } \\
\text { MCM7 }\end{array}$ & 0.59 & $1.51 \times 10^{-5}$ & $12(12)$ & 22.4 & 34.56 \\
\hline$S A F B$ & Scaffold attachment factor B1 & 0.60 & 0.023 & $6(6)$ & 14.6 & 46.12 \\
\hline PSMB2 & Proteasome subunit beta type- 2 & 0.61 & 0.002 & $3(3)$ & 17.9 & 27.04 \\
\hline PSMB4 & Proteasome subunit beta type- 4 & 0.61 & 0.007 & $3(3)$ & 14.8 & 4.97 \\
\hline CCAR2 & $\begin{array}{l}\text { Cell cycle and apoptosis } \\
\text { regulator protein } 2\end{array}$ & 0.62 & 0.002 & $8(8)$ & 13.2 & 22.57 \\
\hline TARDBP & TAR DNA-binding protein 43 & 0.63 & 0.006 & $2(2)$ & 7.2 & 5.87 \\
\hline$A P R T$ & $\begin{array}{l}\text { Adenine } \\
\text { phosphoribosyltransferase }\end{array}$ & 0.64 & 0.004 & $5(5)$ & 37.2 & 43.68 \\
\hline PSMB3 & Proteasome subunit beta type- 3 & 0.64 & $2.35 \times 10^{-4}$ & $4(4)$ & 30.7 & 14.65 \\
\hline$A L D H 1 A 3$ & $\begin{array}{l}\text { Aldehyde dehydrogenase family } \\
1 \text { member A3 }\end{array}$ & 0.65 & 0.001 & $12(12)$ & 28.5 & 57.51 \\
\hline PSMA1 & Proteasome subunit alpha type- 1 & 0.65 & 0.001 & $8(8)$ & 36.9 & 14.21 \\
\hline UHRF1 & $\begin{array}{l}\text { E3 ubiquitin-protein ligase } \\
\text { UHRF1 }\end{array}$ & 0.65 & 0.006 & $8(8)$ & 13.7 & 9.60 \\
\hline CDK1 & Cyclin-dependent kinase 1 & 0.65 & 0.006 & $9(8)$ & 39.4 & 22.58 \\
\hline PSMA3 & Proteasome subunit alpha type-3 & 0.65 & 0.002 & $8(8)$ & 34.1 & 23.82 \\
\hline MCM6 & $\begin{array}{l}\text { DNA replication licensing factor } \\
\text { MCM6 }\end{array}$ & 0.66 & 0.002 & $16(16)$ & 26.4 & 43.74 \\
\hline HSPD1 & $\begin{array}{l}60 \mathrm{kDa} \text { heat shock protein, } \\
\text { mitochondrial }\end{array}$ & 0.66 & 0.001 & $14(14)$ & 34.0 & 108.37 \\
\hline СТВР2 & C-terminal-binding protein 2 & 0.66 & 0.012 & $5(4)$ & 18.2 & 16.52 \\
\hline PSMA5 & Proteasome subunit alpha type- 5 & 0.66 & 0.001 & $7(7)$ & 40.2 & 34.82 \\
\hline
\end{tabular}

${ }^{1}$ Mean ratios calculated from three biological replicates.

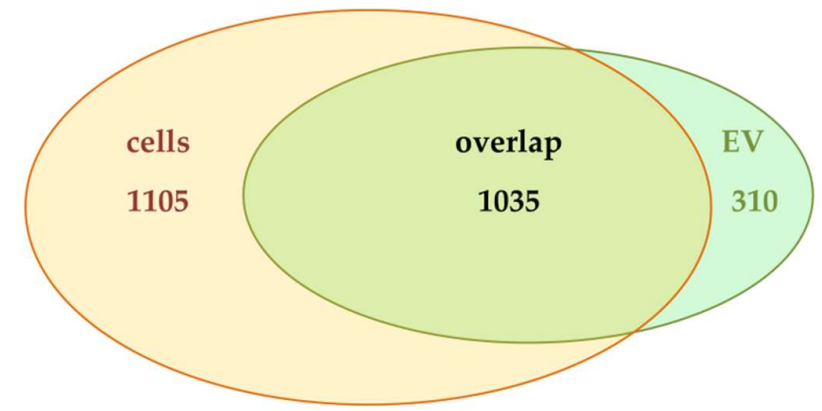

Figure 5. Venn diagram analysis of proteins identified in HCT116-TGFBR2 cells (yellow) and EVs (green) derived thereof. Numbers of proteins per intersection are given.

In order to determine the impact of TGFBR2 deficiency on the cellular proteome, protein ratios $(\mathrm{dT} / \mathrm{pT})$ were calculated and compared to ratios of corresponding EVs. TGFBR2 expression status caused changes in relative EV protein abundance compared to parental cells as shown in the histogram (Supplementary Figure S3). At the cellular level, 14/2140 proteins were regulated in a TGFBR2-dependent manner. Among them, only 3/14 candidates showed statistical significance (Supplementary Table S1).

In summary, these results demonstrate that the majority of TGFBR2-regulated proteins was detected in MSI-derived EVs, but not in parental cells, which suggests that the observed alterations are not simply a consequence of changes in the cellular proteome but rather appear to be EV-specific. 


\subsection{Validation of TGFBR2-Regulated Protein Expression in EVs}

To obtain independent evidence for TGFBR2-regulated proteins identified by mass spectrometry, Western blot analysis was performed on protein lysates of dT- and pT-EVs and parental HCT116-TGFBR2 cells. The two candidates connective tissue growth factor (CTGF) and cyclin-dependent kinase 1 (CDK1) were selected for validation of the downregulated subset, and fibronectin 1 (FN1) and glutamine synthetases (GLUL) were chosen as representative candidates of the upregulated subset. Expression levels of FN1 and GLUL were found to be enriched in dT-EVs compared to pT counterparts, thereby corroborating the expression differences identified by mass spectrometry (Figure 6). Both candidate proteins were almost undetectable in protein lysates of parental cells, although mass spectrometry identified GLUL 1.83-fold upregulated in dT- compared to pT-cells but lacking statistical significance (Supplementary Table S1). In contrast, lower levels of CTGF and CDK1 proteins in dT-EVs compared to pT-EVs indicated downregulation, thus confirming the SILAC-based quantification (Figure 6). The protein CTGF was neither detected in cell lysates by mass spectrometry nor by Western blot analysis.

HCT116-TGFBR2

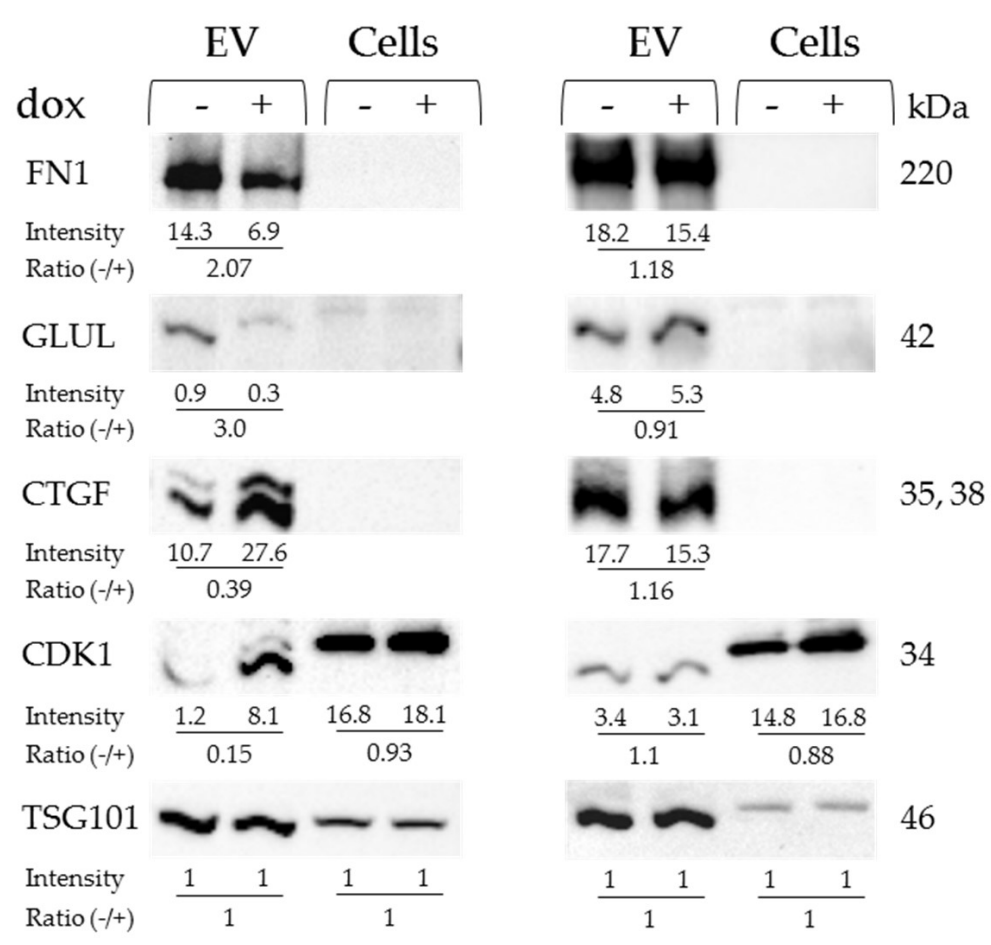

Figure 6. Validation of TGFBR2-regulated EV proteins. Representative TGFBR2-regulated EV proteins (FN1, GLUL, CTGF, CDK1) were analyzed on Western blots in at least two biological replicates. The non-regulated EV marker protein TSG101 was used as a loading control. EVs derived from HCT116-AWE17 cells served as a control for dox-related effects. Band intensities of proteins and calculated ratios are shown below each lane and were normalized to TSG101 set to 1. Protein sizes are indicated.

The expression of the EV marker protein TSG101 remained unaffected by the TGFBR2 expression status. Likewise, TGFBR2-regulated protein changes were not observed in EVs isolated from HCT116-AWE17 cells that lack the dox-inducible TGFBR2 expression switch hence excluding any dox-related effect on EV protein levels. In summary, the observed expression differences of at least some TGFBR2-regulated EV proteins have been proven by two different methods, i.e., Western blot analysis and SILAC-based mass spectrometry. 
2.4. Protein-Protein Network Analysis and Functional Enrichment Analysis of EV Proteins Upregulated by TGFBR2 Deficiency

Mutational inactivation of TGFBR2 is considered to be a recurrent driver event in the progression of MSI tumors. In this context, EV proteins that are upregulated by cellular TGFBR2 deficiency are of particular clinical relevance because knowledge about their function and potential interaction partners might provide some clues about their role in MSI tumor biology. Therefore, information on protein-protein interaction (PPI) obtained from STRING database was used to construct a PPI network of $26 \mathrm{EV}$ proteins found to be upregulated by TGFBR2 deficiency (Figure 7A). A calculated PPI enrichment $p$-value of $6.22 \times 10^{-7}$ confirmed statistical significance of detected protein relations. Among the 26 proteins upregulated in dT-EVs, 11 proteins presented high connectivity in form of visible clusters in the PPI network. Subsequent analysis of functional enrichment revealed that "negative regulation of TGF- $\beta$ secretion (GO:2001202)" was the most significant affected biological process followed by "positive regulation of substrate-dependent cell migration (GO:1904237)", and "DNA conformation change (GO:0071103)" (Figure 7B). In the category of molecular function, the upregulated proteins detected in dT-EV appeared to be enriched in "fibrinogen binding (GO:0070051)", glycosaminoglycan binding (GO:0005539)", and "integrin binding (GO:0005178)" (Figure 7C). These findings indicate that the functional role of EVs in CRCs is impacted by their protein cargo, which can be altered by a single tumor driver mutation.

A

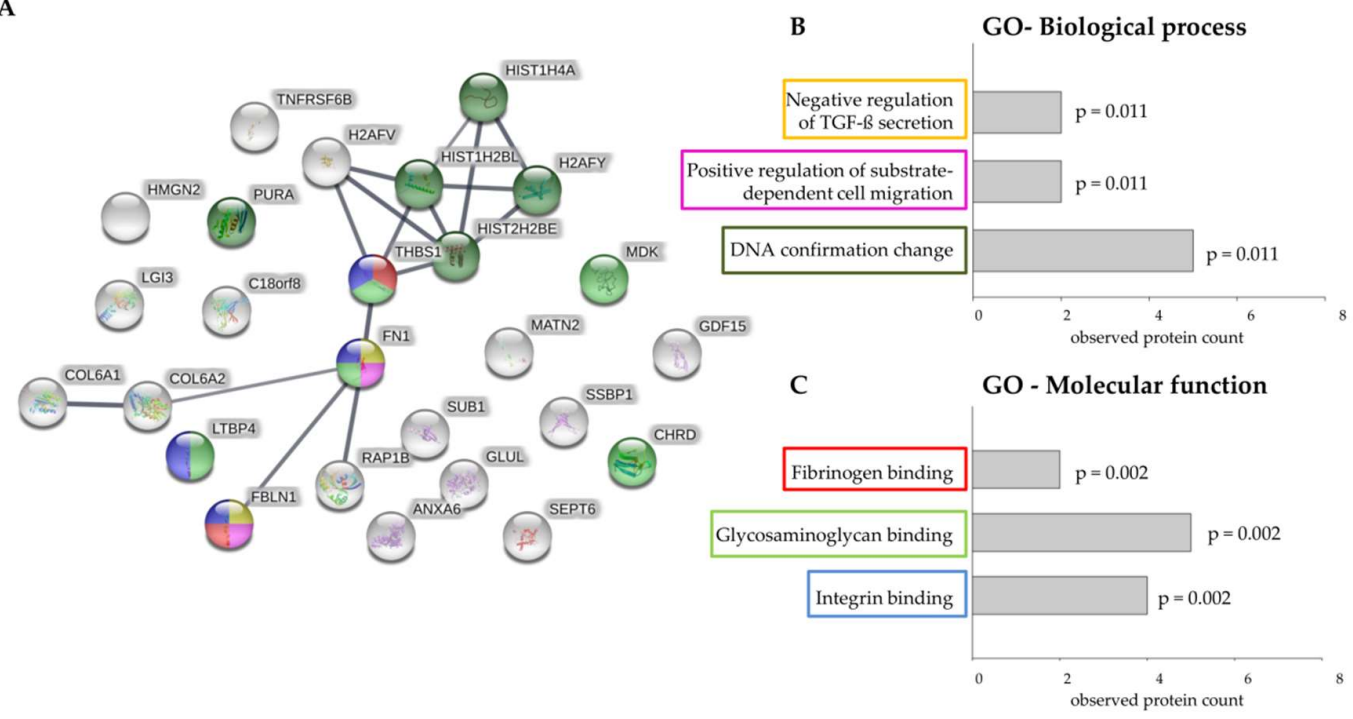

Figure 7. Prediction of protein interactions between upregulated proteins and functional enrichment analysis. (A) Protein interaction map of upregulated proteins identified in TGFBR2-deficient EVs (generated by STRING (v11.0)). The connecting lines between protein nodes represent protein-protein interactions. Line thickness indicates the strength of data support (minimum required interaction score $=0.700$, high confidence). Coloring of proteins is based on functional enrichment analysis. (B) and (C) Visible clusters of the protein-protein interaction map were assigned to enriched ontologies for Biological Processes (B) and Molecular Function (C). Graphs showing most significant enriched Gene Ontology (GO) among the upregulated EV proteins with observed protein count for each category and calculated $p$-value adjusted for multiple comparisons.

\section{Discussion}

Delineation of complex EV cargo changes linked to specific driver mutations is a major challenge due to high heterogeneity of secreted EVs and their parental tumor cells. To overcome this obstacle, we isolated EVs from a TGFBR2-reconsituted MSI CRC model cell line and performed relative protein quantification from dT- and pT-EVs using SILAC labeling. Bottom-up mass spectrometry identified 
48 proteins whose expression was altered in dT-EVs but remained unaffected in parental dT-cells. In independent experiments, we successfully validated the differential expression of four of these TGFBR2-regulated proteins (FN1, GLUL, CTGF, CDK1).

On a technical level, we have established a robust protocol for determining EV cargo alteration caused by TGFBR2 deficiency as demonstrated by high reproducibility between the replicates and the successful validation of TGFBR2-regulated proteins in independent EV samples. Although the majority of proteins was found to be shared between EVs and their parental cells, two subsets of EVand cell-specific proteins were detected. Proteins exclusively quantified in cells might not be sorted into EVs and thus were not identified in EV samples by mass spectrometry. In contrast, we assume that EV-specific proteins were not detected in parental cells due to higher complexity of the cellular proteome [34].

On a biological level, our work emphasizes the capacity of TGFBR2 to alter the protein makeup of EVs and to modulate the molecular message conveyed by these small vesicles. Since the functional role of EVs is determined by their cargo, we hypothesize that altered protein expression levels are biologically relevant and might contribute to the MSI-specific tumor characteristics. In this study, the strongest upregulation was observed for the validated candidate FN1 in dT-EVs. It has been reported that FN1 plays a pro-tumorigenic role in CRC and its downregulation inhibited CRC cell proliferation, migration, and invasion [35-37]. Also, it has been shown that TGFBR2 signaling can induce FN1 expression [38]. This raises the question of how the protein levels of FN1 are increased in dT-EVs as compared to pT-EVs. Although we cannot exclude that TGFBR2 signaling itself might be involved in cargo sorting, other cellular mechanisms might drive the increased sorting of FN1 into dT-EVs. It has been suggested that FN1 is targeted to multivesicular bodies in association with integrins [39], which allows the generation of FN1-expressing EVs ("exosomes") [40]. We have previously reported that reconstituted TGFBR2 signaling can modulate sialylation of cell surface proteins like B1-integrin [32]. Whether an interaction between integrins and FN1 might account for the increased FN1 levels detected in dT-EVs warrants further investigation.

Different studies have identified FN1 in EVs secreted from trophoblasts, breast cancer-, melanoma-, neuroblastoma-, and CRC cells [41-46]. Chen et al. showed that FN1 is upregulated in serum EVs isolated from CRC patients compared to EVs isolated from serum of healthy controls [46]. In line with this observation, it was reported that FN1 is stronger expressed in intestinal tumor tissues compared to normal colon cells [47]. Moreover, a dense infiltration with lymphocytes was associated with high abundance of FN1 [47], which is a typical histopathological feature observed in most primary MSI CRC tumors [2]. However, evidence for the genomic instability status/mutation profile of CRC patients is lacking in the aforementioned study, making it impossible to correlate increased FN1 expression with the patients' TGFBR2 status. To the best of our knowledge, our study provides first time evidence for increased FN1 protein expression in dT-EVs.

Apart from expression analysis, functional studies elucidated that FN1 contains several binding domains for integrins, heparins/heparan sulfates, collagens/gelatins, and fibrins $[48,49]$. It has been demonstrated that FN1 is present on the surface of myeloma cell-derived EVs and can serve as a heparan-binding ligand, which facilitated EV-target cell interactions [43]. FN1-mediated adhesion of EVs to recipients activated intracellular non-canonical TGF- $B$ signaling and target gene expression, which implicates a fundamental mechanism important for EV-mediated crosstalk [43]. Besides serving as a ligand for members of the glycosaminoglycan family, it has been proposed that EV-associated FN1 can bind to integrin surface receptors on macrophages, which leads to pro-inflammatory IL-1 $\beta$ production [41]. The binding capacity of dT-EVs is supported by our functional enrichment analysis. In addition to FN1, the upregulated candidates THBS1, LTBP4, FBLN1, MDK, and CHRD were associated with fibrinogen-, glycosaminoglycan-, integrin binding. Several histones were also detected to be increased in dT-EVs. There is evidence showing that EV-associated histones have a pro-inflammatory activity and can mediate the endocytosis/uptake of EVs by tumor cells that express syndecan-4 [50,51]. Although 
not yet tested in experimental studies, we hypothesize that these upregulated proteins in dT-EVs can promote binding/uptake by specific target cells, which is expected to elicit a biological response.

Such biological responses can for example affect the metabolic activity of recipient cells [52]. Adaption of metabolic pathways is a hallmark of cancer cells, which can favor proliferation and synthesis of biomass [53]. EV-mediated metabolic reprogramming can be caused by their bioactive cargo enzymes and metabolites. For example, cancer-associated fibroblast-derived EVs were found to increase glycolysis and glutamine-dependent reductive carboxylation by inhibiting mitochondrial oxidative phosphorylation in cancer cells [52]. Glutamine can be metabolized from nutrients in the small intestine, but most of the glutamine is generated by de-novo synthesis. GLUL (EC 6.3.1.2) is an adenosine triphosphate (ATP)-dependent enzyme that catalyzes the synthesis of glutamine from glutamate and ammonia. Under glutamine starvation, GLUL can provide de novo purine availability and cell growth in glioblastoma cells [54,55]. According to our data, the enzyme GLUL was found to be upregulated in dT-EVs and downregulated in PT-EVs. This is in line with studies proposing that TGF- $\$$ can reduce the number of GLUL-positive hepatocytes in mice [56] and inhibit the enzymatic activity in mice astrocytes [57]. For the gastrointestinal tract, it was reported that GLUL activity is moderately low in the large intestine [58]. However, we could confirm by Western blot analysis that GLUL is upregulated in dT-EVs.

Apart from upregulated dT-EV proteins, we have also identified a subset of downregulated candidates in dT-EVs. Cellular TGFBR2 deficiency caused the downregulation of $22 \mathrm{EV}$ proteins, many of them associated with the proteasome. The strongest downregulation was detected for the protein PLAU in dT-EVs, which in turn implies that PLAU was upregulated in pT-EVs. Tumor cells modulate their local environment to gain invasive properties by releasing ECM degrading proteases such as PLAU [59]. PLAU can convert plasminogen to plasmin that has a broad substrate repertoire, including FN1 $[60,61]$. In our data, FN1 was identified and previously discussed as the top upregulated candidate in dT-EVs. Interestingly, plasmin can activate latent TGF- $B$ and thus control the bioavailability of the ligand TGF-ß [62]. Besides activating plasmin, PLAU can also modulate a wide range of processes like adhesion, proliferation, and migration by binding to its cell surface receptor uPAR [63]. At the cellular level, it was reported that TGF-B action can induce PLAU expression in human mammalian epithelial cells [64] and cancer cells $[65,66]$. Nevertheless, this paper is the first demonstration on TGF-B-induced PLAU regulation at the vesicular level.

Another known transcriptional target of the TGF- $ß$ pathway is CTGF [67-69], which we have identified and validated to be downregulated in dT-EVs and thus to be enriched in pT-EVs. The protein CTGF has been studied for its involvement in ECM maintenance and modulation. There is evidence that CTGF serves as a pro-fibrogenic mediator downstream of TGF- $[699,70]$. Also, it has been shown that canonical and non-canonical routes of TGF- $\beta$ signaling can induce CTGF expression depending on cell type and context [69]. In addition, CTGF itself can stimulate the TGF-1 pathway by blocking the Smad7-mediated negative feedback loop [71,72]. It has been proposed that breast cancer cells can upregulate Smad7, which in turn leads to decreased ERK signaling and diminished expression of CTGF [73]. For CRC, it has been suggested that reduced CTGF expression can support the invasive capacity [74], which is known to be a characteristic of MSI CRC tumor cells that often grow as large tumors with local invasive properties [4,75]. At the EV level, it was shown that CTGF can be transferred between hepatic stellate cells [76]. However, the specific functional role of EV-associated CTGF has to be elucidated in future experimental studies. In the current paper, we provide the first association between malfunction of intracellular TGF- $\$$ signaling in MSI CRC cells and downregulated levels of CTGF detected in dT-EVs, which is expected to impact fibrotic matrix modulation and signal transduction.

TGFBR2-mediated TGF-ß signaling has been implicated in cell cycle arrest [22]. One key player in cell cycle regulation is CDK1, which was found to be downregulated in dT-EVs. The specific function of the serine/threonine CDK1 is only known at the cellular level. In interaction with its cyclin partners, CDK1 can phosphorylate target substrates, which leads to cell cycle progression. It has been demonstrated that CDK1 can indirectly interact with TGFBR2 via cyclin B2, which leads to cell cycle 
arrest in G1/S phase [77]. Even though CDK1 has been previously identified in the cargo of EVs [33,78], its role has not yet been deciphered at the vesicular level.

In conclusion, the current study provides a comprehensive analysis of proteins in MSI CRC-derived EVs. In particular, SILAC labeling combined with mass spectrometry allowed us to identify $48 \mathrm{EV}$ proteins that turned out to be regulated in a TGFBR2-dependent manner. Although TGF- $B$ signaling and its target genes have been intensively studied at the cellular level, this work provides the first evidence about quantitative differences in EV protein expression caused by TGFBR2 deficiency. It has been reported that dynamics of TGF- $\beta$ signaling can be controlled by ESCRT-mediated TGFBR2 endocytosis [79]. The ESCRT machinery plays an essential role in EV biogenesis and protein cargo sorting [80]. However, whether the interaction of the ESCRT machinery and TGFBR2 expression might have a direct impact on the protein cargo sorting of EVs remains to be resolved. Considering that post-translational modifications can impact the biological activity of EV proteins, the phosphorylation status of these candidates should be analyzed before testing specific functions of TGFBR2-regulated EV proteins in the pathogenesis of MSI tumors.

\section{Materials and Methods}

\subsection{Cell Culture}

HCT116-TGFBR2 and HCT116-AWE17 cells were cultured in DMEM-F12 medium (Thermo Fisher Scientific, Waltham, MA USA) supplemented with 10\% fetal bovine serum (FBS; Thermo Fisher Scientific), $100 \mathrm{U} / \mathrm{mL}$ penicillin and $100 \mu \mathrm{g} / \mathrm{mL}$ streptomycin (Thermo Fisher Scientific) in $5 \% \mathrm{CO}_{2}$ atmosphere at $37^{\circ} \mathrm{C}$. The generation of the doxycycline (dox)-inducible model system HCT116-TGFBR2 has been described previously [32].

\subsection{Stable Isotope Labeling with Amino Acids in Cell Culture (SILAC)}

HCT116-TGFBR2 cells were cultured in SILAC DMEM medium containing either light $\left(\mathrm{L}-\left[{ }^{12} \mathrm{C}_{6},{ }^{14} \mathrm{~N}_{4}\right]\right.$ arginine (Arg0) and $\mathrm{L}-\left[{ }^{12} \mathrm{C}_{6},{ }^{14} \mathrm{~N}_{2}\right]$ lysine (Lys0)) or heavy (L- $\left[{ }^{13} \mathrm{C}_{6},{ }^{15} \mathrm{~N}_{4}\right]$ arginine (+10.0083 Da; Arg10) and L- $\left[{ }^{13} \mathrm{C}_{6},{ }^{15} \mathrm{~N}_{2}\right]$ lysine (+8.0142 Da; Lys8)) forms of $0.798 \mathrm{mM}$ arginine and $0.398 \mathrm{mM}$ lysine (SILANTES, Munich, Germany). The medium was supplemented with $10 \%$ dialyzed FBS and $2 \mathrm{mM}$ L-glutamine (SILANTES). $200 \mu \mathrm{g} / \mathrm{mL}$ of L-proline (Sigma-Aldrich, Taufkrirchen, Germany) were added to the SILAC culture medium in order to prevent arginine-to-proline conversion [81]. To ensure full incorporation of the SILAC labels, the incorporation rate was determined after 10 days of labeling using a published R script [82] and reached $>95 \%$.

\subsection{Doxycycline Hyclate Treatment}

For the SILAC experiment, HCT116-TGFBR2 cells were cultured in the respective SILAC DMEM medium for 14 days. At a confluence of about $80 \%\left(28 \times 10^{6}\right.$ cells/flask $)$, the cells were washed twice with phosphate-buffered saline (PBS; Thermo Fisher Scientific) and subsequently cultured for $16 \mathrm{~h}$ in minimal volumes $(17 \mathrm{~mL} / \mathrm{T} 175)$ of the respective serum-free SILAC medium containing $10 \mathrm{ng} / \mathrm{mL}$ TGF- $\$ 1$ (Abcam, Cambridge, UK), $2 \mathrm{mM}$ L-glutamine, and either light or heavy forms of arginine and lysine. Heavy-labeled HCT116-TGFBR2 cells were treated with $0.5 \mu \mathrm{g} / \mathrm{mL}$ doxycycline hyclate (dox; Sigma-Aldrich) to induce reconstituted expression of TGFBR2 (heavy state: TGFBR2-proficient, pT). Light-labeled HCT116-TGFBR2 cells were cultivated in the absence of dox and remained TGFBR2-deficient (light state: TGFBR2-deficient, dT). The SILAC experiment was performed in triplicates. For validation experiments, HCT116-TGFBR2 and HCT116-AWE17 cells were also cultured for $16 \mathrm{~h}$ in the presence and absence of dox in serum-free DMEM-F12 medium supplemented with TGF-B1. 


\subsection{EV Preparation}

For EV isolation, culture medium was collected and stored on ice until further processing. Each EV replicate was obtained from $5 \times$ T175 flasks of HCT116-TGFBR2 or HCT116-AWE17 cells. Cells were also harvested and stored at $-20{ }^{\circ} \mathrm{C}$ until protein extraction was performed. Cell culture medium was subjected to sequential centrifugations as previously reported [31]. Briefly, floating cells $\left(480 \times g, 4{ }^{\circ} \mathrm{C}, 10 \mathrm{~min}\right)$, and cellular debris $\left(2000 \times g, 4{ }^{\circ} \mathrm{C}, 10 \mathrm{~min}\right)$ were removed. Supernatants were passed through a $0.22 \mu \mathrm{m}$ filter and concentrated (40-fold) to a final volume of $1 \mathrm{~mL}$ using 10,000 molecular weight cut-off Vivaspin 20 centrifugal concentrators (Sartorius, Göttingen, Germany) and by centrifugation at $4000 \times g$ at $4{ }^{\circ} \mathrm{C}$. Total Exosome Isolation Reagent (Thermo Fisher Scientific) was added according to the manufacturer's instructions. After addition of miniComplete EDTA-free protease inhibitor cocktail (Roche Diagnostics, Mannheim, Germany) and PhosStop phosphatase inhibitor cocktail (Roche Diagnostics), the samples were incubated on a rotating wheel overnight at $4{ }^{\circ} \mathrm{C}$ followed by centrifugation $\left(10,000 \times g, 1 \mathrm{~h}, 4{ }^{\circ} \mathrm{C}\right)$. EV pellets were lysed in RIPA buffer supplemented with miniComplete EDTA-free protease inhibitor and PhosStop phosphatase inhibitor (Roche Diagnostics) for protein extraction [83] or resuspended in particle-free PBS for EV identification.

\subsection{Transmission Electron Microscopy (TEM)}

Five microliters of EV suspensions in particle-free PBS were left to settle onto 100 mesh formvar-coated copper grids (Plano, Wetzlar, Germany), contrasted with $2 \%$ aqueous uranyl acetate (negative stain), air-dried and visualized using a JEM-1400 transmission microscope (JEOL, Peabody, MA, USA) equipped with a Tietz $2 \mathrm{~K}$ digital camera (TVIPS, Gauting, Germany) at $80 \mathrm{KV}$.

\subsection{Nanoparticle Tracking Analysis (NTA)}

Size profiles and particle concentrations were assessed by nanoparticle tracking analysis (NTA) using the ZetaView PMX-220 TWIN Laser system with software 8.05.05 SP2 (Particle Metrix, Inning, Germany) according to the manufacturer's instructions. EV suspensions were diluted 1:3000 (v/v) in particle-free PBS and analyzed at 11 different positions. Data acquisition thresholds were set to a shutter of 100 , a sensitivity of $90 \%$, and a frame rate of 30 frames per second.

\subsection{Protein Extraction and Determination of Protein Concentration}

Cellular and EV proteins from both TGFBR2 conditions were extracted in RIPA (50 mM Tris- $\mathrm{HCl}$ pH 7.4, $150 \mathrm{mM} \mathrm{NaCl}, 1 \%$ Triton X-100, 1\% sodium-deoxycholate, $0.1 \%$ SDS, $0.1 \mathrm{mM} \mathrm{CaCl}, 0.01 \mathrm{mM}$ $\mathrm{MgCl}_{2}$ ) buffer [83] supplemented with miniComplete EDTA-free protease inhibitor and PhosStop phosphatase inhibitor. $250 \mathrm{U} / \mathrm{mL}$ of benzonase nuclease (Merck, Darmstadt, Germany) were added to the cell lysates to eliminate nucleic acids. EV and cell lysates were incubated at $4{ }^{\circ} \mathrm{C}$ on a rotating wheel for $2 \mathrm{~h}$. After centrifugation at $20,000 \times \mathrm{g}$ for $30 \mathrm{~min}$ at $4{ }^{\circ} \mathrm{C}$, protein concentration of supernatants was determined using 2-D Quant Kit reagents (GE Healthcare, Uppsala, Sweden) for proteome analysis or by Bradford assay (Bio-Rad, Hercules, USA) for Western blot analysis according to the manufacturer's instructions.

\subsection{In-Solution Tryptic Digestion}

Protein lysates from corresponding light ( $\mathrm{dT}$ ) and heavy (pT) labeled samples were mixed in a 1:1 ratio based on their protein concentration (cells: $10 \mu \mathrm{g}$; EVs: $210 \mu \mathrm{g}$ ). In order to remove EV Isolation Reagent and protease inhibitors, quantitative protein precipitation was performed in a methanol-chloroform-water mixture according to Wessel and Flugge [84]. Precipitated proteins were dissolved in $10 \mu \mathrm{L}$ (cells) or $135 \mu \mathrm{L}$ (EVs) $40 \mathrm{mM} \mathrm{NH}_{4} \mathrm{HCO}_{3}$ (Fluka, Steinheim, Germany) and incubated at $25^{\circ} \mathrm{C}$ for $1 \mathrm{~h}$ in a thermomixer at $600 \mathrm{rpm}$. Protein disulfide bonds were completely reduced by $2 \mathrm{mM}$ dithiothreitol (DTT; AppliChem, Darmstadt, Germany) in $40 \mathrm{mM} \mathrm{NH} \mathrm{NCO}_{3}$ at $45^{\circ} \mathrm{C}$ for $1 \mathrm{~h}$ at $600 \mathrm{rpm}$. Thiol groups were alkylated by the addition of iodoacetamide (IAA; Sigma, 
St. Louis, MO, USA) in $40 \mathrm{mM} \mathrm{NH}_{4} \mathrm{HCO}_{3}$ at a final concentration of $5 \mathrm{mM}$. Samples were incubated in the dark at $25^{\circ} \mathrm{C}$ for $30 \mathrm{~min}$ at $600 \mathrm{rpm}$ followed by the addition of DTT to a final concentration of $4 \mathrm{mM}$ and incubation at $37^{\circ} \mathrm{C}$ for $15 \mathrm{~min}$ at $600 \mathrm{rpm}$. In-solution digestion was performed overnight at $37^{\circ} \mathrm{C}$ with $0.1 \mu \mathrm{g}$ (cells) and $2.1 \mu \mathrm{g}$ (EVs) trypsin (Promega, Fitchburg, MA, USA). Due to high peptide concentration, additional $1 \mu \mathrm{g}$ of typsin were added to the EV samples and incubated at $37^{\circ} \mathrm{C}$ for $3 \mathrm{~h} .5 \mathrm{ug}$ of each EV peptide mixture were transferred into new tubes. Tryptic peptide mixtures were vacuum-dried in a speed-vac and stored at $-20^{\circ} \mathrm{C}$ until proteome analysis. Newly information added, please confirm.

\subsection{Nano-LC-ESI-MS/MS}

Tryptic EV peptides ( $1 \mu \mathrm{g} /$ replicate) were redissolved in $0.1 \%$ trifluoroacetic acid/ $2.5 \%$ hexafluoroisopropanol and separated using a nanoAcquity UPLC system (Waters, Eschborn, Germany). Peptides were trapped on a C18 column $(180 \mu \mathrm{m} \times 20 \mathrm{~mm})$ with a particle size of $5 \mu \mathrm{m}$ (Waters). Liquid chromatography separation was performed on a BEH130 C18 main-column $(100 \mu \mathrm{m} \times 100 \mathrm{~mm})$ with a particle size of $1.7 \mu \mathrm{m}$ (Waters) at a flow rate of $400 \mathrm{~nL} / \mathrm{min}$. Each EV sample was fractionated using a $3 \mathrm{~h}$ gradient of solvent A ( $1 \%$ acetonitrile, $0.1 \%$ formic acid) and solvent $\mathrm{B}(99.9 \%$ acetonitrile, $0.1 \%$ formic acid) in the following sequence: From $0 \%$ to $4 \% \mathrm{~B}$ in $1 \mathrm{~min}$, from $4 \%$ to $25 \% \mathrm{~B}$ in $139 \mathrm{~min}$, from $25 \%$ to $40 \%$ B in $15 \mathrm{~min}$, from $40 \%$ to $85 \%$ B in $10 \mathrm{~min}, 5 \mathrm{~min}$ at $85 \% \mathrm{~B}$, from $85 \%$ to $4 \%$ B in $2 \mathrm{~min}$, and $15 \mathrm{~min}$ at $4 \% \mathrm{~B}$. The nanoUPLC system was coupled online to an LTQ Orbitrap XL mass spectrometer (Thermo Fisher Scientific) using a nanoESI interface. Following parameters were set: ESI voltage $2000 \mathrm{~V}$; capillary temperature $200{ }^{\circ} \mathrm{C}$, normalized collision energy $35 \mathrm{~V}$. Data acquisition was performed with Xcalibur software by scan cycles of one Fourier transform mass spectrometry (FTMS) scan with a resolution of 60,000 at $\mathrm{m} / \mathrm{z} 400$ and a range from 300 to $2000 \mathrm{~m} / \mathrm{z}$ in parallel with six MS/MS scans in the ion trap of the most abundant precursor ions.

Cellular peptides mixtures $(1 \mu \mathrm{g} /$ replicate) were separated using the Dionex UltiMate 3000 nanoUPLC system (Thermo Scientific, Bremen, Germany). Peptides were trapped on an Acclaim Pepmap 100 column, $100 \mu \mathrm{m} \times 20 \mathrm{~mm}$, particle size $5 \mu \mathrm{m}$ (Thermo Scientific). The liquid chromatography separation was performed on a C18 column (Acclaim Pepmap RSLC, $75 \mu \mathrm{m} \times 50 \mathrm{~cm}$, particle size $2 \mu \mathrm{m}$ (Thermo Scientific) with a flow rate of $300 \mathrm{~nL} / \mathrm{min}$. Chromatography was carried out using a $2 \mathrm{~h}$ gradient of solvent C $(99.9 \%$ water, $0.1 \%$ formic acid) and solvent D ( $80 \%$ acetonitrile, $19.9 \%$ water, $0.1 \%$ formic acid) in the following sequence: $2 \mathrm{~min}$ at $2 \% \mathrm{D}$, from $2 \%$ to $8 \% \mathrm{D}$ in $1 \mathrm{~min}$, from $8 \%$ to $25 \% \mathrm{D}$ in $80 \mathrm{~min}$, from $25 \%$ to $40 \% \mathrm{D}$ in $10 \mathrm{~min}$, from $40 \%$ to $95 \% \mathrm{D}$ in $1 \mathrm{~min}, 5 \mathrm{~min}$ at $95 \% \mathrm{D}$, from 95 to $2 \% \mathrm{D}$ in $1 \mathrm{~min}$, and $20 \mathrm{~min}$ at $2 \% \mathrm{D}$. The nanoUPLC system was coupled online to a $\mathrm{Q}$ Exactive HF-X Hybrid Quadrupole-Orbitrap mass spectrometer (Thermo Scientific). Following parameters were set: ESI voltage $2200 \mathrm{~V}$; capillary temperature $275^{\circ} \mathrm{C}$, normalized collision energy $35 \mathrm{~V}$. Data were acquired by scan cycles of one FTMS scan with a resolution of 120,000 at m/z 200 and a range from 300 to $2000 \mathrm{~m} / \mathrm{z}$ in parallel with ten MS/MS scans in the ion trap of the most abundant precursor ions.

The mass spectrometry proteomics raw files have been deposited to the ProteomeXchange Consortium [85] (http://proteomecentral.proteomexchange.org) via the PRIDE partner repository [86] with the dataset identifier PXD013980.

\subsection{Protein Identification and Quantification}

LC-MS/MS raw data was imported to MaxQuant software (version 1.6.3.3) [87]. Peptides were identified using Andromeda search engine [88] against the SwissProt database (download: 01/03/2019; Homo sapiens: 20,412 entries). Enzyme specificity was set to trypsin/p and two missed cleavage sites in case of incomplete trypsin hydrolysis were permitted. A minimum peptide length of 7 amino acids was required. Cysteine carbamidomethylation (C) was set as fixed modification, whereas methionine oxidation $(\mathrm{M})$, asparagine and glutamine deamidation $(\mathrm{NQ})$, and protein $N$-terminal acetylation were considered as variable modifications. According to the SILAC labeling, no labeling or double labeling (Arg10 and Lys8) were selected with maximum of 3 labeled amino acids per peptide. Mass tolerances 
were defined for precursor and fragmented ions as follows: MS first search-20 ppm, MS main search-6 ppm, and MS/MS-0.5 Da. Identification was performed under a false discovery rate (FDR) of 0.01. SILAC-based quantification was based on unique and razor peptides with a minimum of two ratio counts. Peptide ratios were calculated and normalized for each arginine- and/or lysine-containing peptide as described [89].

\subsection{Data Analysis}

Data analysis was performed using Perseus (version 1.6.1.3) [90,91] and R software (version 3.5.0) with the following packages: forcats_0.4.0, stringr_1.4.0, dplyr_0.8.0.1, purrr_0.3.2, readr_1.3.1, tidyr_0.8.3, tibble_2.1.1, tidyverse_1.2.1, ggrepel_0.8.0, ggplot2_3.1.0, and readxl_1.3.1. Proteins derived from decoy database containing reversed protein sequences, common contaminants (EVs: KRT1, KRT8, KRT19, DMKN, TPM4, mouse KRT18, bovine GSN; cells: KRT1, KRT8, KRT10, KRT19, KRT82, GSN, MT1X) as well as proteins identified by site modification only were strictly excluded from further analysis. Proteins identified with at least two unique peptides and quantified in at least 2 out of 3 biological replicates were considered for further analysis. To define significantly regulated proteins between TGFBR2-proficient (pT; heavy state) and TGFBR2-deficient (dT; light state) conditions, fold changes ( $\mathrm{dT} / \mathrm{pT}$ ratios) were calculated and $\log _{2}$ transformation was performed. In order to identify significant TGFBR2-regulated proteins, one-sample $t$ tests were conducted with null hypothesis assuming that the difference in protein ratios between replicates equals 0 . Obtained $p$-values were adjusted for multiple testing according to Benjamini and Hochberg [92]. After applying an adjusted $p$-value of $\leq 0.05$ as a cut-off, proteins were only classified as significantly regulated if their abundance changed more than 1.5- or less than 0.667 -fold $(\log 2 \geq|0.585|)$ between the TGFBR2 conditions. Enrichment analysis of regulated proteins was performed in STRING [93] (version 11.0) for Gene Ontology Biological Processes (GO BP) and Gene Ontology Molecular Functions (GO MF).

\subsection{SDS Page and Western Blot}

Protein extracts $(40 \mu \mathrm{g} / \mathrm{sample})$ were separated on $4-20 \%$ Bis-Tris gradient gels (Expedeon, San Diego, CA, USA) and blotted onto a nitrocellulose membrane (Life Technologies, Carlsbad, CA, USA). After blocking membranes in 5\% milk/TBST, the following primary antibodies were used: Mouse anti-CD63 (1:800, clone MX-49.129.5, Santa Cruz, Heidelberg, Germany), mouse anti-CD9 (1:100, clone C-4, Santa Cruz), mouse anti-CD81 (1:1000, clone TS81, Abcam), mouse anti- $\beta$-Actin (1:2000, clone C4, MP Biomedicals, Eschwege, Germany), goat anti-Alix (1:800, sc-49268, Santa Cruz), mouse anti-TSG101 (1:500, clone 4A10, Thermo Fisher Scientific), mouse anti-CNX (1:500, clone E-10, Santa Cruz), mouse anti-FN1 (1:1000, clone A-11, Santa Cruz), rabbit anti-CTGF (1:1000; \#86641, Cell Signaling), mouse anti-GLUL (1:100, clone E-4, Santa Cruz), rabbit anti-CDK1 (1:1000, \#77055, Cell Signaling), mouse anti-TGFBR2 (1:300, clone D2, Santa Cruz), rabbit anti-Smad2 (1:1000, clone 86F7, Cell Signaling), and rabbit anti-pSmad2 (1:1000, Ser465/467, Cell Signaling). Diluted primary antibodies were incubated with membranes overnight at $4{ }^{\circ} \mathrm{C}$. The blots were washed with TBST and incubated with a sheep anti-mouse-IgG HRP (1:5000; GE Healthcare), goat anti-rabbit-IgG HRP (1:2500, Promega) or donkey anti-goat-IgG HRP (1:1000, Santa Cruz) secondary antibody for $1 \mathrm{~h}$ at room temperature (RT). Signals were detected using Western Lightning Plus ECL (Perkin Elmer, Waltham, MA, USA) and a ChemiDoc MP System (Bio-Rad).

Supplementary Materials: Supplementary Materials can be found at http://www.mdpi.com/1422-0067/20/17/ 4162/s1.

Author Contributions: J.G., J.K., M.M., and F.F. designed the experiments. F.F., I.H. and U.W. performed the experiments. F.F., J.G., J.K., M.M., U.W. and M.S. analyzed the data. F.F., J.G. and J.K. wrote the manuscript. All authors read and approved the final manuscript.

Funding: This work was supported by intramural funding from the University Hospital Heidelberg (J.G., J.K.) and the Stiftung für Krebs- und Scharlachforschung (F.F) 
Acknowledgments: The excellent technical support of Ulrike Ganserer, Sigrun Himmelsbach, and Vera Fuchs is highly appreciated. We thank Simon Kalteis for kind support in information technology. The encouragement of the Claussen-Simon-Stiftung is gratefully acknowledged.

Conflicts of Interest: The authors declare no conflict of interest.

\section{Abbreviations}

$\begin{array}{ll}\text { CRC } & \text { Colorectal cancer } \\ \text { Dox } & \text { Doxycycline } \\ \text { dT } & \text { Transforming Growth Factor Beta Receptor Type 2-deficient } \\ \text { ECM } & \text { Extracellular matrix } \\ \text { EVs } & \text { Extracellular vesicles } \\ \text { FTMS } & \text { Fourier transform mass spectrometry } \\ \text { MISEV } & \text { Minimal information for studies of extracellular vesicles } \\ \text { MSI } & \text { Microsatellite instability } \\ \text { PPI } & \text { Protein-protein interaction } \\ \text { pT } & \text { Transforming Growth Factor Beta Receptor Type 2-proficient } \\ \text { SILAC } & \text { Stable isotope labeling with amino acids in cell culture } \\ \text { TGFBR2 } & \text { Transforming Growth Factor Beta Receptor Type 2 }\end{array}$

\section{References}

1. Boland, C.R.; Goel, A. Microsatellite instability in colorectal cancer. Gastroenterology 2010, 138, $2073-2087$. [CrossRef] [PubMed]

2. Kloor, M.; Staffa, L.; Ahadova, A.; von Knebel Doeberitz, M. Clinical significance of microsatellite instability in colorectal cancer. Langenbecks Arch. Surg. 2014, 399, 23-31. [CrossRef] [PubMed]

3. Li, S.K.H.; Martin, A. Mismatch Repair and Colon Cancer: Mechanisms and Therapies Explored. Trends Mol. Med. 2016, 22, 274-289. [CrossRef] [PubMed]

4. Buckowitz, A.; Knaebel, H.P.; Benner, A.; Blaker, H.; Gebert, J.; Kienle, P.; von Knebel Doeberitz, M.; Kloor, M. Microsatellite instability in colorectal cancer is associated with local lymphocyte infiltration and low frequency of distant metastases. Br. J. Cancer 2005, 92, 1746-1753. [CrossRef] [PubMed]

5. Malesci, A.; Laghi, L.; Bianchi, P.; Delconte, G.; Randolph, A.; Torri, V.; Carnaghi, C.; Doci, R.; Rosati, R.; Montorsi, M.; et al. Reduced likelihood of metastases in patients with microsatellite-unstable colorectal cancer. Clin. Cancer Res. 2007, 13, 3831-3839. [CrossRef] [PubMed]

6. Popat, S.; Hubner, R.; Houlston, R.S. Systematic review of microsatellite instability and colorectal cancer prognosis. J. Clin. Oncol. 2005, 23, 609-618. [CrossRef] [PubMed]

7. Devaud, N.; Gallinger, S. Chemotherapy of MMR-deficient colorectal cancer. Fam. Cancer 2013, 12, 301-306. [CrossRef] [PubMed]

8. Le, D.T.; Durham, J.N.; Smith, K.N.; Wang, H.; Bartlett, B.R.; Aulakh, L.K.; Lu, S.; Kemberling, H.; Wilt, C.; Luber, B.S.; et al. Mismatch repair deficiency predicts response of solid tumors to PD-1 blockade. Science 2017, 357, 409-413. [CrossRef]

9. Lemery, S.; Keegan, P.; Pazdur, R. First FDA Approval Agnostic of Cancer Site-When a Biomarker Defines the Indication. N. Engl. J. Med. 2017, 377, 1409-1412. [CrossRef]

10. Woerner, S.M.; Benner, A.; Sutter, C.; Schiller, M.; Yuan, Y.P.; Keller, G.; Bork, P.; von Knebel Doeberitz, M.; Gebert, J. Pathogenesis of DNA repair-deficient cancers: A statistical meta-analysis of putative Real Common Target genes. Oncogene 2003, 22, 2226-2235. [CrossRef]

11. Woerner, S.M.; Gebert, J.; Yuan, Y.P.; Sutter, C.; Ridder, R.; Bork, P.; von Knebel Doeberitz, M. Systematic identification of genes with coding microsatellites mutated in DNA mismatch repair-deficient cancer cells. Int. J. Cancer 2001, 93, 12-19. [CrossRef] [PubMed]

12. Jonchere, V.; Marisa, L.; Greene, M.; Virouleau, A.; Buhard, O.; Bertrand, R.; Svrcek, M.; Cervera, P.; Goloudina, A.; Guillerm, E.; et al. Identification of Positively and Negatively Selected Driver Gene Mutations Associated With Colorectal Cancer With Microsatellite Instability. Cell Mol. Gastroenterol. Hepatol. 2018, 6, 277-300. [CrossRef] [PubMed] 
13. Biswas, S.; Trobridge, P.; Romero-Gallo, J.; Billheimer, D.; Myeroff, L.L.; Willson, J.K.; Markowitz, S.D.; Grady, W.M. Mutational inactivation of TGFBR2 in microsatellite unstable colon cancer arises from the cooperation of genomic instability and the clonal outgrowth of transforming growth factor beta resistant cells. Genes Chromosomes Cancer 2008, 47, 95-106. [CrossRef] [PubMed]

14. Markowitz, S.; Wang, J.; Myeroff, L.; Parsons, R.; Sun, L.; Lutterbaugh, J.; Fan, R.S.; Zborowska, E.; Kinzler, K.W.; Vogelstein, B.; et al. Inactivation of the type II TGF-beta receptor in colon cancer cells with microsatellite instability. Science 1995, 268, 1336-1338. [CrossRef] [PubMed]

15. Biswas, S.; Chytil, A.; Washington, K.; Romero-Gallo, J.; Gorska, A.E.; Wirth, P.S.; Gautam, S.; Moses, H.L.; Grady, W.M. Transforming growth factor beta receptor type II inactivation promotes the establishment and progression of colon cancer. Cancer Res. 2004, 64, 4687-4692. [CrossRef] [PubMed]

16. Grady, W.M.; Myeroff, L.L.; Swinler, S.E.; Rajput, A.; Thiagalingam, S.; Lutterbaugh, J.D.; Neumann, A.; Brattain, M.G.; Chang, J.; Kinzler, K.W.; et al. Mutational inactivation of transforming growth factor beta receptor type II in microsatellite stable colon cancers. Cancer Res. 1999, 59, 320-324. [PubMed]

17. Meng, X.; Vander Ark, A.; Lee, P.; Hostetter, G.; Bhowmick, N.A.; Matrisian, L.M.; Williams, B.O.; Miranti, C.K.; $\mathrm{Li}, \mathrm{X}$. Myeloid-specific TGF-beta signaling in bone promotes basic-FGF and breast cancer bone metastasis. Oncogene 2016, 35, 2370-2378. [CrossRef] [PubMed]

18. Li, X.; Placencio, V.; Iturregui, J.M.; Uwamariya, C.; Sharif-Afshar, A.R.; Koyama, T.; Hayward, S.W.; Bhowmick, N.A. Prostate tumor progression is mediated by a paracrine TGF-beta/Wnt3a signaling axis. Oncogene 2008, 27, 7118-7130. [CrossRef]

19. Copland, J.A.; Luxon, B.A.; Ajani, L.; Maity, T.; Campagnaro, E.; Guo, H.; LeGrand, S.N.; Tamboli, P.; Wood, C.G. Genomic profiling identifies alterations in TGFbeta signaling through loss of TGFbeta receptor expression in human renal cell carcinogenesis and progression. Oncogene 2003, 22, 8053-8062. [CrossRef]

20. Batlle, E.; Massague, J. Transforming Growth Factor-beta Signaling in Immunity and Cancer. Immunity 2019, 50, 924-940. [CrossRef]

21. Derynck, R.; Zhang, Y.E. Smad-dependent and Smad-independent pathways in TGF-beta family signalling. Nature 2003, 425, 577-584. [CrossRef] [PubMed]

22. Massague, J. TGFbeta signalling in context. Nat. Rev. Mol. Cell Biol. 2012, 13, 616-630. [CrossRef] [PubMed]

23. Massague, J. TGFbeta in Cancer. Cell 2008, 134, 215-230. [CrossRef] [PubMed]

24. Stahl, P.D.; Raposo, G. Exosomes and extracellular vesicles: The path forward. Essays Biochem. 2018, 62, 119-124. [CrossRef] [PubMed]

25. Van Niel, G.; D'Angelo, G.; Raposo, G. Shedding light on the cell biology of extracellular vesicles. Nat. Rev. Mol. Cell Biol. 2018, 19, 213-228. [CrossRef]

26. Thery, C.; Witwer, K.W.; Aikawa, E.; Alcaraz, M.J.; Anderson, J.D.; Andriantsitohaina, R.; Antoniou, A.; Arab, T.; Archer, F.; Atkin-Smith, G.K. Minimal information for studies of extracellular vesicles 2018 (MISEV2018): A position statement of the International Society for Extracellular Vesicles and update of the MISEV2014 guidelines. J. Extracell. Vesicles 2018, 7, 1535750. [CrossRef] [PubMed]

27. Becker, A.; Thakur, B.K.; Weiss, J.M.; Kim, H.S.; Peinado, H.; Lyden, D. Extracellular Vesicles in Cancer: Cell-to-Cell Mediators of Metastasis. Cancer Cell 2016, 30, 836-848. [CrossRef]

28. Mathieu, M.; Martin-Jaular, L.; Lavieu, G.; Thery, C. Specificities of secretion and uptake of exosomes and other extracellular vesicles for cell-to-cell communication. Nat. Cell Biol. 2019, 21, 9-17. [CrossRef]

29. Anand, S.; Samuel, M.; Kumar, S.; Mathivanan, S. Ticket to a bubble ride: Cargo sorting into exosomes and extracellular vesicles. Biochim. Biophys. Acta Proteins Proteom 2019. [CrossRef]

30. Wu, A.Y.; Ueda, K.; Lai, C.P. Proteomic Analysis of Extracellular Vesicles for Cancer Diagnostics. Proteomics 2019, 19, e1800162. [CrossRef]

31. Fricke, F.; Lee, J.; Michalak, M.; Warnken, U.; Hausser, I.; Suarez-Carmona, M.; Halama, N.; Schnölzer, M.; Kopitz, J.; Gebert, J. TGFBR2-dependent alterations of exosomal cargo and functions in DNA mismatch repair-deficient HCT116 colorectal cancer cells. Cell Commun. Signal. 2017, 15, 14. [CrossRef]

32. Lee, J.; Ballikaya, S.; Schonig, K.; Ball, C.R.; Glimm, H.; Kopitz, J.; Gebert, J. Transforming growth factor beta receptor 2 (TGFBR2) changes sialylation in the microsatellite unstable (MSI) Colorectal cancer cell line HCT116. PLoS ONE 2013, 8, e57074. [CrossRef]

33. Pathan, M.; Fonseka, P.; Chitti, S.V.; Kang, T.; Sanwlani, R.; Van Deun, J.; Hendrix, A.; Mathivanan, S. Vesiclepedia 2019: A compendium of RNA, proteins, lipids and metabolites in extracellular vesicles. Nucleic Acids Res. 2019, 47, 516-519. [CrossRef] 
34. Bosque, A.; Dietz, L.; Gallego-Lleyda, A.; Sanclemente, M.; Iturralde, M.; Naval, J.; Alava, M.A.; Martinez-Lostao, L.; Thierse, H.J.; Anel, A. Comparative proteomics of exosomes secreted by tumoral Jurkat $\mathrm{T}$ cells and normal human $\mathrm{T}$ cell blasts unravels a potential tumorigenic role for valosin-containing protein. Oncotarget 2016, 7, 29287-29305. [CrossRef]

35. Cai, X.; Liu, C.; Zhang, T.N.; Zhu, Y.W.; Dong, X.; Xue, P. Down-regulation of FN1 inhibits colorectal carcinogenesis by suppressing proliferation, migration, and invasion. J. Cell Biochem. 2018, 119, 4717-4728. [CrossRef]

36. Wu, J.; Wang, Y.; Xu, X.; Cao, H.; Sahengbieke, S.; Sheng, H.; Huang, Q.; Lai, M. Transcriptional activation of FN1 and IL11 by HMGA2 promotes the malignant behavior of colorectal cancer. Carcinogenesis 2016, 37, 511-521. [CrossRef]

37. Ding, J.; Li, D.; Wang, X.; Wang, C.; Wu, T. Fibronectin promotes invasiveness and focal adhesion kinase tyrosine phosphorylation of human colon cancer cell. Hepatogastroenterology 2008, 55, 2072-2076.

38. Ignotz, R.A.; Massague, J. Transforming growth factor-beta stimulates the expression of fibronectin and collagen and their incorporation into the extracellular matrix. J. Biol. Chem. 1986, 261, 4337-4345.

39. Lobert, V.H.; Brech, A.; Pedersen, N.M.; Wesche, J.; Oppelt, A.; Malerod, L.; Stenmark, H. Ubiquitination of alpha 5 beta 1 integrin controls fibroblast migration through lysosomal degradation of fibronectin-integrin complexes. Dev. Cell 2010, 19, 148-159. [CrossRef]

40. Sung, B.H.; Ketova, T.; Hoshino, D.; Zijlstra, A.; Weaver, A.M. Directional cell movement through tissues is controlled by exosome secretion. Nat. Commun. 2015, 6, 7164. [CrossRef]

41. Atay, S.; Gercel-Taylor, C.; Taylor, D.D. Human trophoblast-derived exosomal fibronectin induces pro-inflammatory IL-1beta production by macrophages. Am. J. Reprod. Immunol. 2011, 66, 259-269. [CrossRef]

42. Moon, P.G.; Lee, J.E.; Cho, Y.E.; Lee, S.J.; Chae, Y.S.; Jung, J.H.; Kim, I.S.; Park, H.Y.; Baek, M.C. Fibronectin on circulating extracellular vesicles as a liquid biopsy to detect breast cancer. Oncotarget 2016, 7, 40189-40199. [CrossRef]

43. Purushothaman, A.; Bandari, S.K.; Liu, J.; Mobley, J.A.; Brown, E.E.; Sanderson, R.D. Fibronectin on the Surface of Myeloma Cell-derived Exosomes Mediates Exosome-Cell Interactions. J. Biol. Chem. 2016, 291, 1652-1663. [CrossRef]

44. Deng, Z.; Cheng, Z.; Xiang, X.; Yan, J.; Zhuang, X.; Liu, C.; Jiang, H.; Ju, S.; Zhang, L.; Grizzle, W.; et al. Tumor cell cross talk with tumor-associated leukocytes leads to induction of tumor exosomal fibronectin and promotes tumor progression. Am. J. Pathol. 2012, 180, 390-398. [CrossRef]

45. Marimpietri, D.; Petretto, A.; Raffaghello, L.; Pezzolo, A.; Gagliani, C.; Tacchetti, C.; Mauri, P.; Melioli, G.; Pistoia, V. Proteome profiling of neuroblastoma-derived exosomes reveal the expression of proteins potentially involved in tumor progression. PLoS ONE 2013, 8, e75054. [CrossRef]

46. Chen, Y.; Xie, Y.; Xu, L.; Zhan, S.; Xiao, Y.; Gao, Y.; Wu, B.; Ge, W. Protein content and functional characteristics of serum-purified exosomes from patients with colorectal cancer revealed by quantitative proteomics. Int. J. Cancer 2017, 140, 900-913. [CrossRef]

47. Kida, H.; Takano, Y.; Yamamoto, K.; Mori, M.; Yanaga, K.; Tanaka, J.; Kudo, S.E.; Mimori, K. A single nucleotide polymorphism in fibronectin 1 determines tumor shape in colorectal cancer. Oncol. Rep. 2014, 32, 548-552. [CrossRef]

48. Pankov, R.; Yamada, K.M. Fibronectin at a glance. J. Cell Sci. 2002, 115, 3861-3863. [CrossRef]

49. Mosher, D. Fibronectin, 1st ed.; Elsevier: San Diego, CA, 1989; pp. 1-492.

50. Ochieng, J.; Nangami, G.; Sakwe, A.; Rana, T.; Ingram, S.; Goodwin, J.S.; Moye, C.; Lammers, P.; Adunyah, S.E. Extracellular histones are the ligands for the uptake of exosomes and hydroxyapatite-nanoparticles by tumor cells via syndecan-4. FEBS Lett. 2018, 592, 3274-3285. [CrossRef]

51. Burke, M.C.; Oei, M.S.; Edwards, N.J.; Ostrand-Rosenberg, S.; Fenselau, C. Ubiquitinated proteins in exosomes secreted by myeloid-derived suppressor cells. J. Proteome Res. 2014, 13, 5965-5972. [CrossRef]

52. Zhao, H.; Yang, L.; Baddour, J.; Achreja, A.; Bernard, V.; Moss, T.; Marini, J.C.; Tudawe, T.; Seviour, E.G.; San Lucas, F.A.; et al. Tumor microenvironment derived exosomes pleiotropically modulate cancer cell metabolism. Elife 2016, 5, e10250. [CrossRef]

53. DeBerardinis, R.J.; Lum, J.J.; Hatzivassiliou, G.; Thompson, C.B. The biology of cancer: Metabolic reprogramming fuels cell growth and proliferation. Cell Metab. 2008, 7, 11-20. [CrossRef] 
54. Tajan, M.; Hock, A.K.; Blagih, J.; Robertson, N.A.; Labuschagne, C.F.; Kruiswijk, F.; Humpton, T.J.; Adams, P.D.; Vousden, K.H. A Role for p53 in the Adaptation to Glutamine Starvation through the Expression of SLC1A3. Cell Metab. 2018, 28, 721-736. [CrossRef]

55. Tardito, S.; Oudin, A.; Ahmed, S.U.; Fack, F.; Keunen, O.; Zheng, L.; Miletic, H.; Sakariassen, P.O.; Weinstock, A.; Wagner, A.; et al. Glutamine synthetase activity fuels nucleotide biosynthesis and supports growth of glutamine-restricted glioblastoma. Nat. Cell Biol. 2015, 17, 1556-1568. [CrossRef]

56. Ueberham, E.; Arendt, E.; Starke, M.; Bittner, R.; Gebhardt, R. Reduction and expansion of the glutamine synthetase expressing zone in livers from tetracycline controlled TGF-beta1 transgenic mice and multiple starved mice. J. Hepatol. 2004, 41, 75-81. [CrossRef]

57. Chao, C.C.; Hu, S.; Tsang, M.; Weatherbee, J.; Molitor, T.W.; Anderson, W.R.; Peterson, P.K. Effects of transforming growth factor-beta on murine astrocyte glutamine synthetase activity. Implications in neuronal injury. J. Clin. Invest. 1992, 90, 1786-1793. [CrossRef]

58. James, L.; Lunn, P.; Middleton, S.; Elia, M. Distribution of glutaminase and glutamine synthetase activities in the human gastrointestinal tract. Clin. Sci. 1998, 94, 313-319. [CrossRef]

59. Duffy, M.J. Urokinase-type plasminogen activator: A potent marker of metastatic potential in human cancers. Biochem. Soc. Trans. 2002, 30, 207-210. [CrossRef]

60. Bekes, E.M.; Deryugina, E.I.; Kupriyanova, T.A.; Zajac, E.; Botkjaer, K.A.; Andreasen, P.A.; Quigley, J.P. Activation of pro-uPA is critical for initial escape from the primary tumor and hematogenous dissemination of human carcinoma cells. Neoplasia 2011, 13, 806-821. [CrossRef]

61. Quigley, J.P.; Gold, L.I.; Schwimmer, R.; Sullivan, L.M. Limited cleavage of cellular fibronectin by plasminogen activator purified from transformed cells. Proc. Natl. Acad. Sci. USA 1987, 84, 2776-2780. [CrossRef]

62. Lyons, R.M.; Gentry, L.E.; Purchio, A.F.; Moses, H.L. Mechanism of activation of latent recombinant transforming growth factor beta 1 by plasmin. J. Cell Biol. 1990, 110, 1361-1367. [CrossRef]

63. Planus, E.; Barlovatz-Meimon, G.; Rogers, R.A.; Bonavaud, S.; Ingber, D.E.; Wang, N. Binding of urokinase to plasminogen activator inhibitor type-1 mediates cell adhesion and spreading. J. Cell Sci. 1997, 110, 1091-1098.

64. Stampfer, M.R.; Yaswen, P.; Alhadeff, M.; Hosoda, J. TGF beta induction of extracellular matrix associated proteins in normal and transformed human mammary epithelial cells in culture is independent of growth effects. J. Cell Physiol. 1993, 155, 210-221. [CrossRef]

65. Lang, D.S.; Marwitz, S.; Heilenkotter, U.; Schumm, W.; Behrens, O.; Simon, R.; Reck, M.; Vollmer, E.; Goldmann, T. Transforming growth factor-beta signaling leads to uPA/PAI-1 activation and metastasis: A study on human breast cancer tissues. Pathol. Oncol. Res. 2014, 20, 727-732. [CrossRef]

66. Santibanez, J.F. Transforming growth factor-Beta and urokinase-type plasminogen activator: Dangerous partners in tumorigenesis-implications in skin cancer. ISRN Dermatol. 2013, 2013, 597927. [CrossRef]

67. Lau, L.F. Cell surface receptors for CCN proteins. J. Cell Commun. Signal. 2016, 10, 121-127. [CrossRef]

68. Brunner, A.; Chinn, J.; Neubauer, M.; Purchio, A.F. Identification of a gene family regulated by transforming growth factor-beta. DNA Cell Biol. 1991, 10, 293-300. [CrossRef]

69. Leask, A.; Parapuram, S.K.; Shi-Wen, X.; Abraham, D.J. Connective tissue growth factor (CTGF, CCN2) gene regulation: A potent clinical bio-marker of fibroproliferative disease? J. Cell Commun. Signal. 2009, 3, 89-94. [CrossRef]

70. Mori, T.; Kawara, S.; Shinozaki, M.; Hayashi, N.; Kakinuma, T.; Igarashi, A.; Takigawa, M.; Nakanishi, T.; Takehara, K. Role and interaction of connective tissue growth factor with transforming growth factor- $\beta$ in persistent fibrosis: A mouse fibrosis model. J. Cell Physiol. 1999, 181, 153-159. [CrossRef]

71. Wahab, N.A.; Weston, B.S.; Mason, R.M. Modulation of the TGFbeta/Smad signaling pathway in mesangial cells by CTGF/CCN2. Exp. Cell Res. 2005, 307, 305-314. [CrossRef]

72. Qi, W.; Chen, X.; Twigg, S.; Zhang, Y.; Gilbert, R.E.; Kelly, D.J.; Pollock, C.A. The differential regulation of Smad7 in kidney tubule cells by connective tissue growth factor and transforming growth factor-beta1. Nephrology 2007, 12, 267-274. [CrossRef]

73. van Rooyen, B.A.; Schafer, G.; Leaner, V.D.; Parker, M.I. Tumour cells down-regulate CCN2 gene expression in co-cultured fibroblasts in a Smad7- and ERK-dependent manner. Cell Commun. Signal. 2013, 11, 75. [CrossRef]

74. Lin, B.R.; Chang, C.C.; Che, T.F.; Chen, S.T.; Chen, R.J.; Yang, C.Y.; Jeng, Y.M.; Liang, J.T.; Lee, P.H.; Chang, K.J.; et al. Connective tissue growth factor inhibits metastasis and acts as an independent prognostic marker in colorectal cancer. Gastroenterology 2005, 128, 9-23. [CrossRef] 
75. Jung, S.H.; Kim, S.H.; Kim, J.H. Prognostic Impact of Microsatellite Instability in Colorectal Cancer Presenting With Mucinous, Signet-Ring, and Poorly Differentiated Cells. Ann. Coloproctol. 2016, 32, 58-65. [CrossRef]

76. Charrier, A.; Chen, R.; Chen, L.; Kemper, S.; Hattori, T.; Takigawa, M.; Brigstock, D.R. Exosomes mediate intercellular transfer of pro-fibrogenic connective tissue growth factor (CCN2) between hepatic stellate cells, the principal fibrotic cells in the liver. Surgery 2014, 156, 548-555. [CrossRef]

77. Liu, J.H.; Wei, S.; Burnette, P.K.; Gamero, A.M.; Hutton, M.; Djeu, J.Y. Functional association of TGF-beta receptor II with cyclin B. Oncogene 1999, 18, 269-275. [CrossRef]

78. Tauro, B.J.; Greening, D.W.; Mathias, R.A.; Ji, H.; Mathivanan, S.; Scott, A.M.; Simpson, R.J. Comparison of ultracentrifugation, density gradient separation, and immunoaffinity capture methods for isolating human colon cancer cell line LIM1863-derived exosomes. Methods 2012, 56, 293-304. [CrossRef]

79. Miller, D.S.J.; Bloxham, R.D.; Jiang, M.; Gori, I.; Saunders, R.E.; Das, D.; Chakravarty, P.; Howell, M.; Hill, C.S. The Dynamics of TGF-beta Signaling Are Dictated by Receptor Trafficking via the ESCRT Machinery. Cell Rep. 2018, 25, 1841-1855. [CrossRef]

80. Colombo, M.; Moita, C.; van Niel, G.; Kowal, J.; Vigneron, J.; Benaroch, P.; Manel, N.; Moita, L.F.; Thery, C.; Raposo, G. Analysis of ESCRT functions in exosome biogenesis, composition and secretion highlights the heterogeneity of extracellular vesicles. J. Cell Sci. 2013, 126, 5553-5565. [CrossRef]

81. Lossner, C.; Warnken, U.; Pscherer, A.; Schnölzer, M. Preventing arginine-to-proline conversion in a cell-line-independent manner during cell cultivation under stable isotope labeling by amino acids in cell culture (SILAC) conditions. Anal. Biochem. 2011, 412, 123-125. [CrossRef]

82. Letzel, T. Protein and Peptide Analysis by LC-MS: Experimental Strategies. Anal. Bioanal. Chem. 2012, 402, 2481-2482.

83. Ngoka, L.C. Sample prep for proteomics of breast cancer: Proteomics and gene ontology reveal dramatic differences in protein solubilization preferences of radioimmunoprecipitation assay and urea lysis buffers. Proteome Sci. 2008, 6, 30. [CrossRef]

84. Wessel, D.; Flugge, U.I. A method for the quantitative recovery of protein in dilute solution in the presence of detergents and lipids. Anal. Biochem. 1984, 138, 141-143. [CrossRef]

85. Deutsch, E.W.; Csordas, A.; Sun, Z.; Jarnuczak, A.; Perez-Riverol, Y.; Ternent, T.; Campbell, D.S.; Bernal-Llinares, M.; Okuda, S.; Kawano, S.; et al. The ProteomeXchange consortium in 2017: Supporting the cultural change in proteomics public data deposition. Nucleic Acids Res. 2017, 45, 1100-1106. [CrossRef]

86. Perez-Riverol, Y.; Csordas, A.; Bai, J.; Bernal-Llinares, M.; Hewapathirana, S.; Kundu, D.J.; Inuganti, A.; Griss, J.; Mayer, G.; Eisenacher, M.; et al. The PRIDE database and related tools and resources in 2019: Improving support for quantification data. Nucleic Acids Res. 2018, 47, 442-450. [CrossRef]

87. Tyanova, S.; Temu, T.; Cox, J. The MaxQuant computational platform for mass spectrometry-based shotgun proteomics. Nat. Protoc. 2016, 11, 2301-2319. [CrossRef]

88. Cox, J.; Neuhauser, N.; Michalski, A.; Scheltema, R.A.; Olsen, J.V.; Mann, M. Andromeda: A peptide search engine integrated into the MaxQuant environment. J. Proteome Res. 2011, 10, 1794-1805. [CrossRef]

89. Cox, J.; Mann, M. MaxQuant enables high peptide identification rates, individualized p.p.b.-range mass accuracies and proteome-wide protein quantification. Nat. Biotechnol. 2008, 26, 1367-1372. [CrossRef]

90. Tyanova, S.; Cox, J. Perseus: A Bioinformatics Platform for Integrative Analysis of Proteomics Data in Cancer Research. Methods Mol. Biol. 2018, 1711, 133-148.

91. Tyanova, S.; Temu, T.; Sinitcyn, P.; Carlson, A.; Hein, M.Y.; Geiger, T.; Mann, M.; Cox, J. The Perseus computational platform for comprehensive analysis of (prote)omics data. Nat. Methods 2016, 13, 731-740. [CrossRef]

92. Benjamini, Y.; Hochberg, Y. Controlling the False Discovery Rate: A Practical and Powerful Approach to Multiple Testing. J. R. Stat. Soc. Ser. A Stat. Soc. 1995, 57, 289-300. [CrossRef]

93. Szklarczyk, D.; Gable, A.L.; Lyon, D.; Junge, A.; Wyder, S.; Huerta-Cepas, J.; Simonovic, M.; Doncheva, N.T.; Morris, J.H.; Bork, P.; et al. STRING v11: Protein-protein association networks with increased coverage, supporting functional discovery in genome-wide experimental datasets. Nucleic Acids Res. 2019, 47, 607-613. [CrossRef]

(C) 2019 by the authors. Licensee MDPI, Basel, Switzerland. This article is an open access article distributed under the terms and conditions of the Creative Commons Attribution (CC BY) license (http://creativecommons.org/licenses/by/4.0/). 